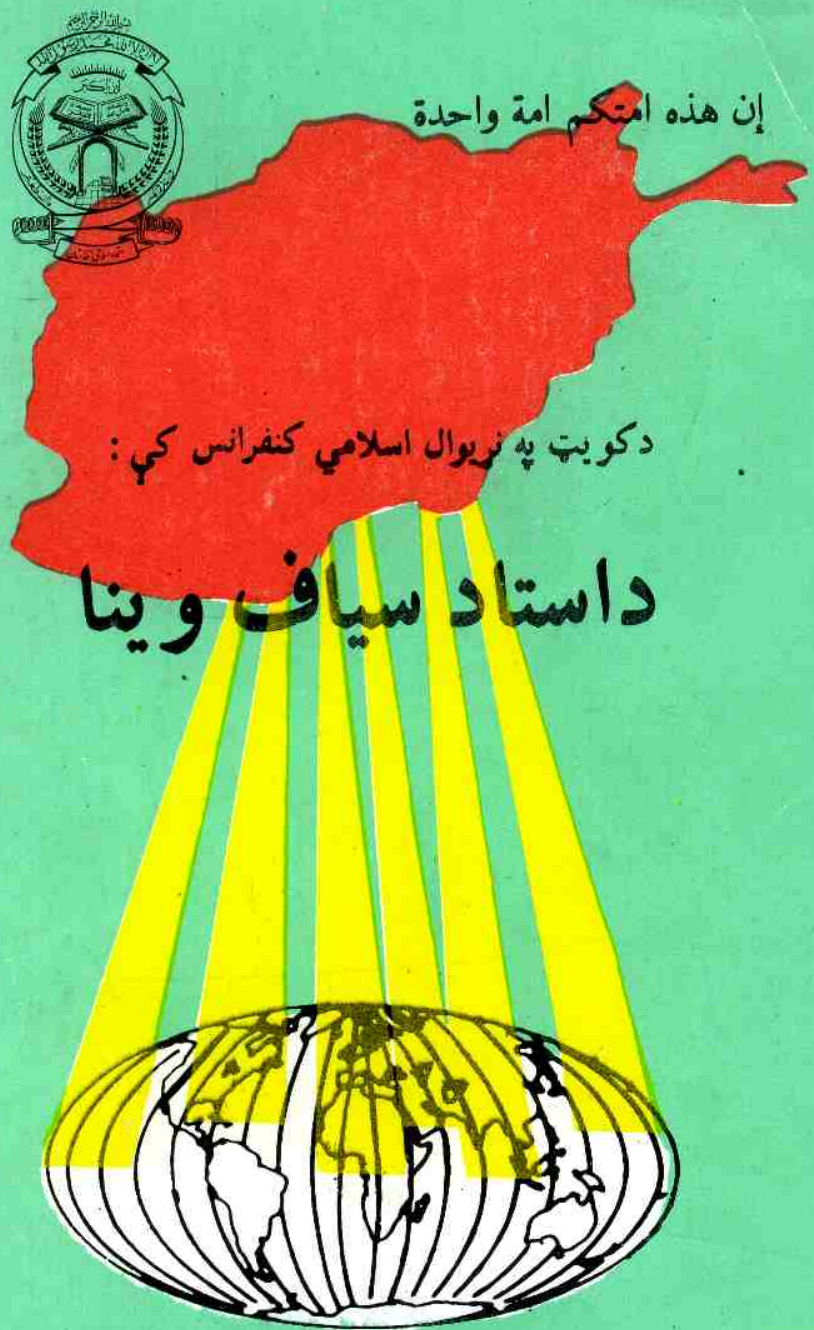


c

إن مذه امتكم امة واحدة

دكربت به نريوال اسلامي كثرانس كمي :

داستاد سياف و ينا

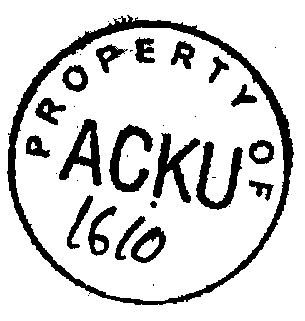




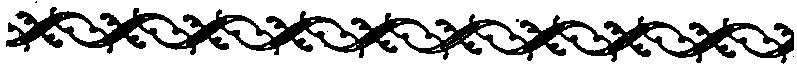

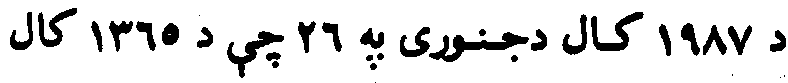

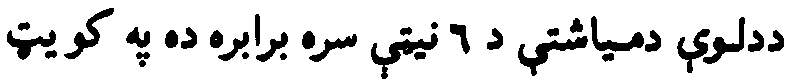

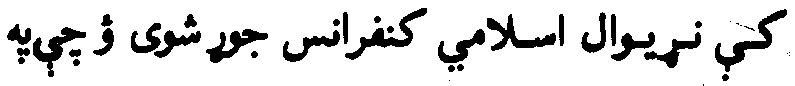
منه كي دافغانستان د اوو جهادي تنظيمونومشرانو

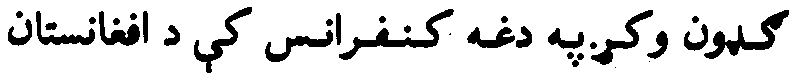

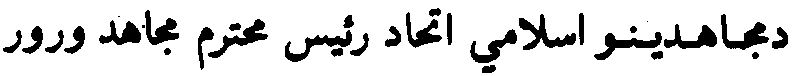
استـاد ((سياف )) يوه مفصله و ينا وكره جِبِ دمغبِ توره متن بِ دغه رسال كي وراندب كور.
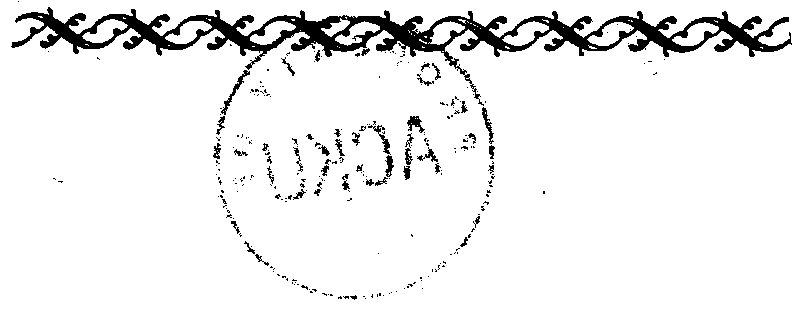


$$
\text { بسم الله الرحمن الرحيم }
$$

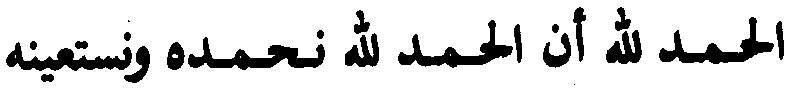
ونســفــره ونعـوذ بـالله مـن شـرورأنفسنا

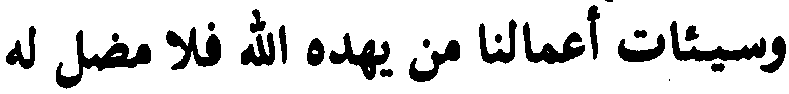

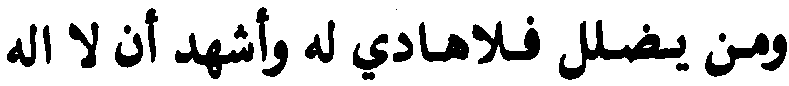
الاالله وحـده لا شريك له وأشهد أن محمداً عبده ورسوله أرسله الله بالمقى بشيراً ونذيراً بين يديالساعة ، اللهم صل وسلم وبارك على مذاالنبسى الكريم امام المتقين وقائد المبتجامدين حبـيبنا وحبيب رب العالمين

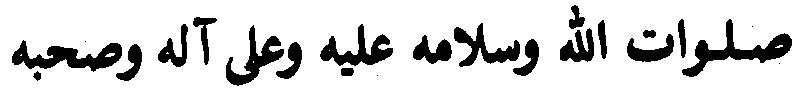

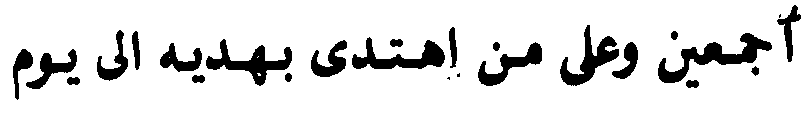
- الدين 
أما بعد ! فأعرذ بالله من الشيطان الرجيم -

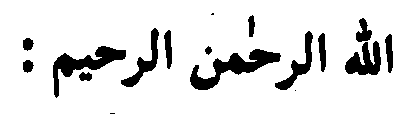

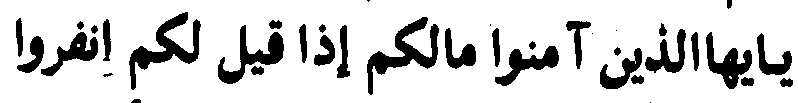

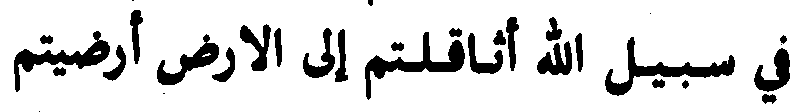
بالميساة الدينا من الآخرة فها متاع الحياة

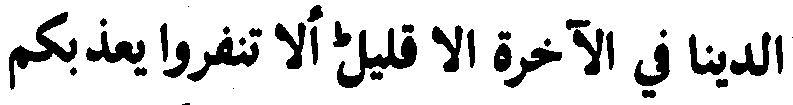

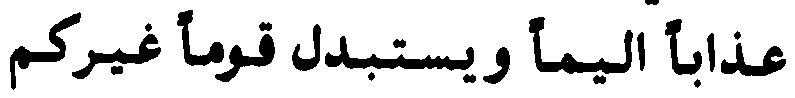
ولا تضروه شيثاً.والله عل كل شيء قدئ قدير. صدق الله العظيم

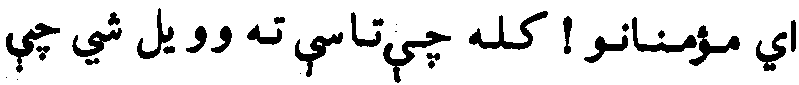

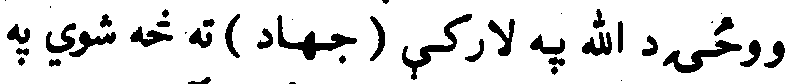

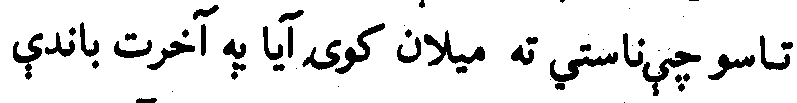

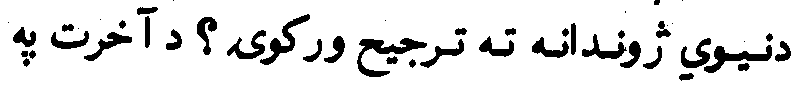

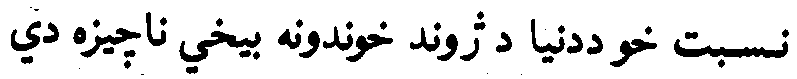


ـ كه لارنشى ( جهـاد ) ته الله (ج) به تـاسي ؛ه دردوونكي عذاب اخته كري .

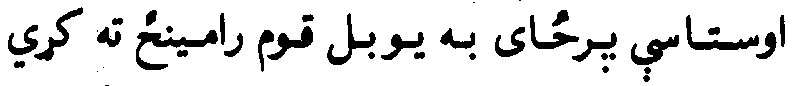

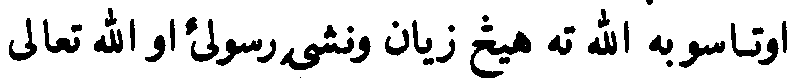
به مرخه قادردئ .

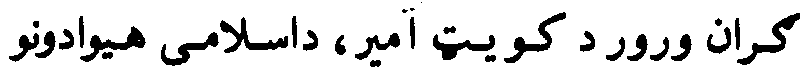

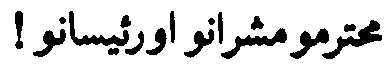

خوشحاله يم جه دافغانستان د اوو جهادي

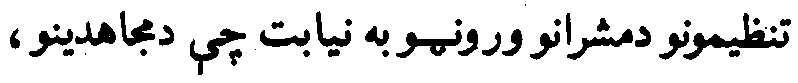

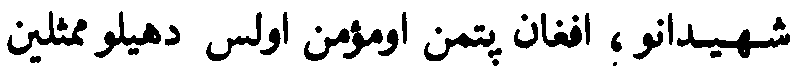

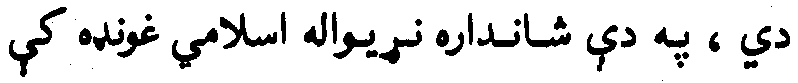
تـاسـوته داسـلامى مسنونه سوغات به وراندي كولو

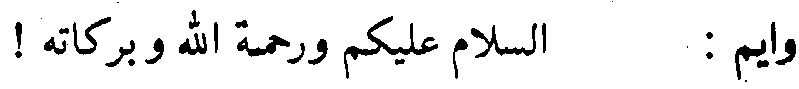
همـدارازخبيل تحيات اوبني هيلب له همدي حُايه د محمد صلى الله عليه وسلم تول امت ته ، هنه $r$ 
امست ته جهي دفتسحي اونصرت وعده ورسره شوي وراندي كوم .

لهكه خنكه جي دقهرمان افغانستان د بجاهدو بيجيانو دجهـاد دســكـرونو دزمريانو ، د ذلت دحُنحُيرونو

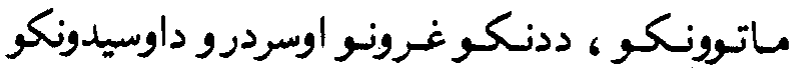
تحيـات اوسـلامـونسه هـم درته وراندي كوم ، دهغو

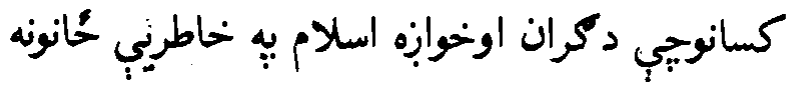
قر بـان كرل ددعوت اوجهاذ كرونده يبي به جيلو بـاكوو ينو خزو به كره ... اوداسلأمى امت دعزت

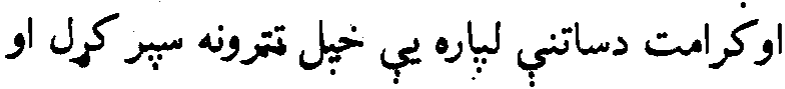
دالله تعالى به مـرسته خجيل جهاد ته ادامه وركوي

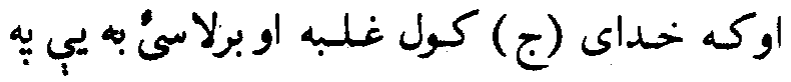
برخه وي -

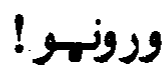

دافغانستان مسلمان ملت به كلكه د خجل دين 
يبيروي كوي ، به خبِلي عقيدي و يازي له اسلامي

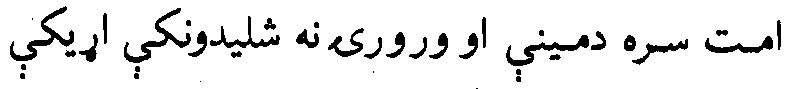

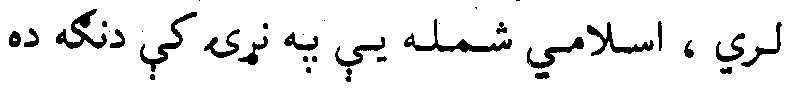

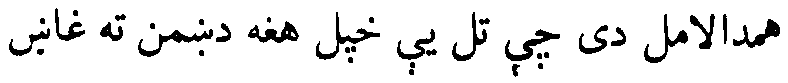

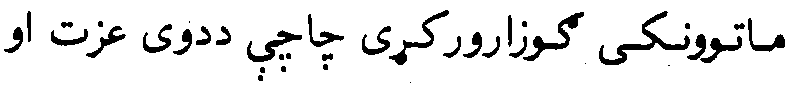

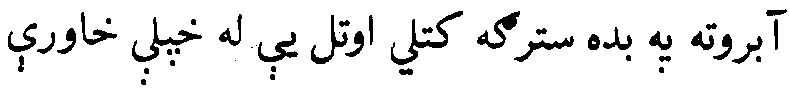

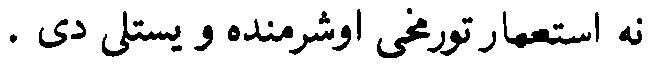

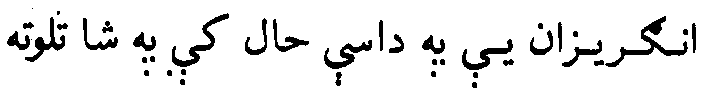

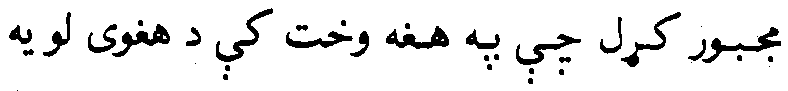

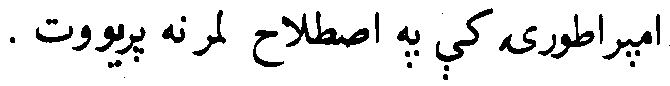
افغانستان د تاريخ به اوزدو كي داسلامي لور شان إنهان

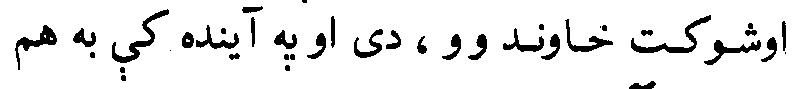

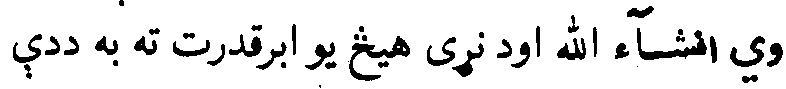

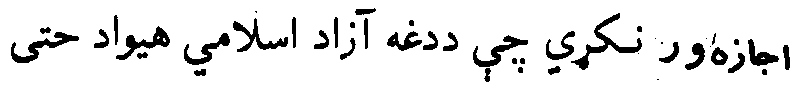
يوه لو يشت مُمه اشغال كري . 


\section{محترمو ورونو!}

مسلمان افغانستان :جب د اسلامي نزيريوه نه بيليدونكي برخه ده ددي هجري بيرى يبليز سرخط يبي د اتلوليو او بريالتوبونويه هغوز رينو كربنو وليكه جي ديد تهول اسلامي امت له ياره د عزت سرمشت شو

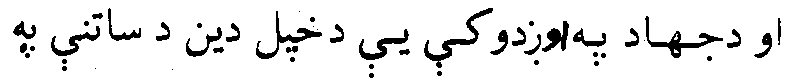
خـاطر له يومليون خخه زيات شهيدان وركرل ـ به لكونو كسان يبي بي لاسونو ، بى بِبنو او بنديان شول

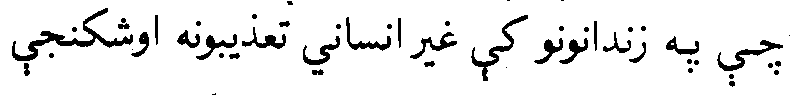
و يسنسي ،كلي اوكورونه يي د توبونو به كوليز اوبمباريو بيه كنهن والو بدل شول او به مليونو خلك يبي هجرت

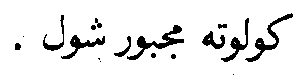

ددي هـيـواد دغـرونسورغونو،كليو اونبارونوهلارو اوكـوخـو لـو يـشــت لو يشت دهغه د بيجيانوبه و ينو

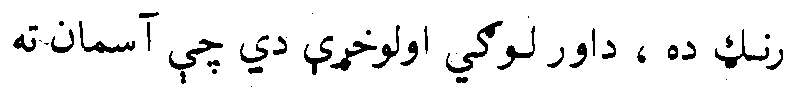


بورته كيبزي او دآسمانونو اومُمكى مالك ته دسبيني بيرو . ماشومانو ، اوسبين سرو فريادونه له يُانه سره ويري لكته به هيخٍ داسب يو كور ونه موندل شي تجيهيه هغه

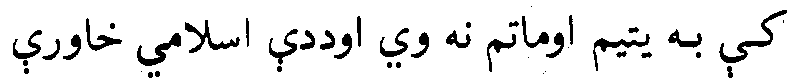

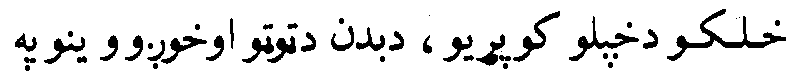

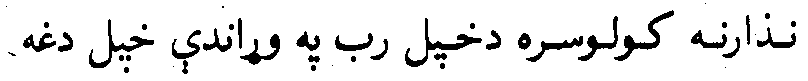
مسسئوليت اداكي جي دخبل وس اوتوان تروروستي دئي سرحسه ددغه دين خخه ددفاع به لاركي يجي سيما

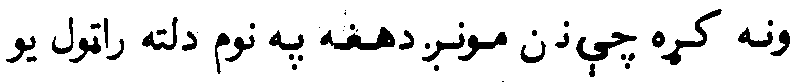

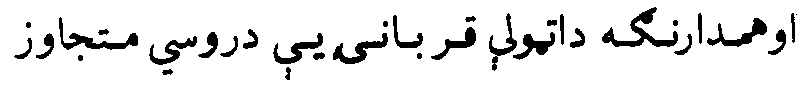

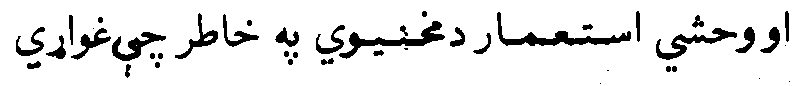

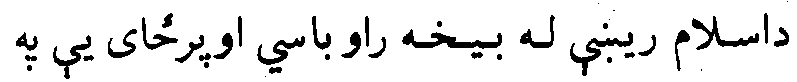
اسلامي تولنو كي دكفر اوالحاد مفكوو مسلطه كري

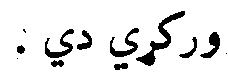




\section{خوبج:وورونو}

بحاهد افغانستان دالله تعالى بِ توفيق اومرسته وكولى شول بي دعصر ستر طاغوت رايه كوندو كري .

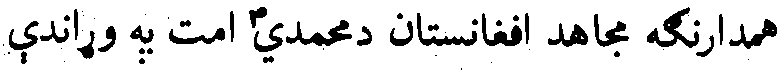
داثابته كره جي دا امت دمُمكي يرمخ كولى شئي آزاد يتـمسن اوسرلورى زونـد وكري او دهيجا اسارت

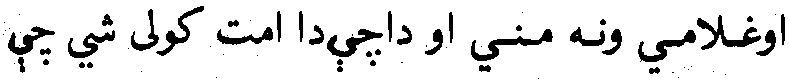

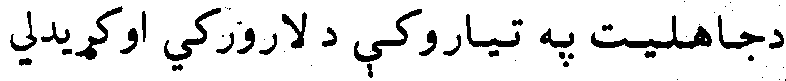
بسـريت لاس نيوى وكري اودغرقوونكي سمندر له

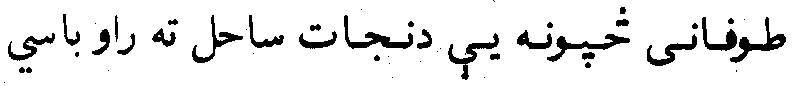

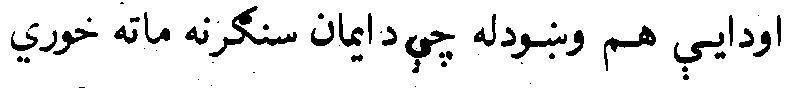

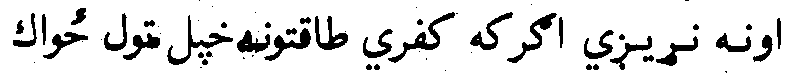

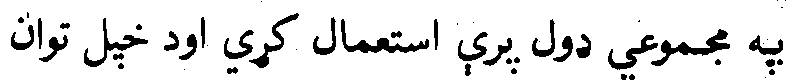

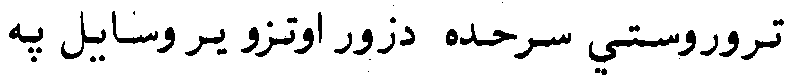

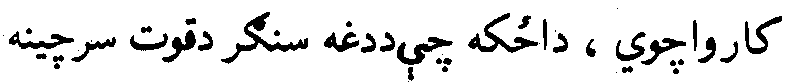




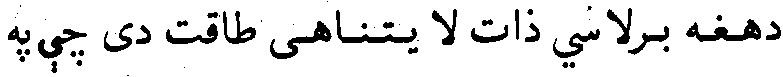

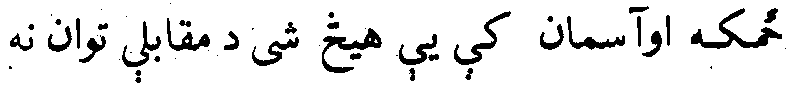
لري هغه ترتولو لوى اولوردى .

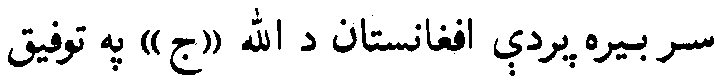

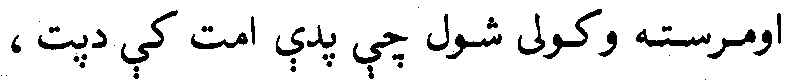

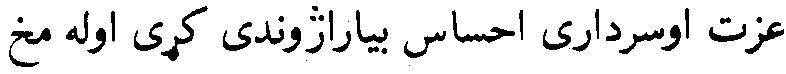
نه يب د خوارى اوذلت دوي إِ دتل لِّاره وختندي . ورونو!

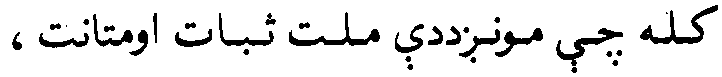

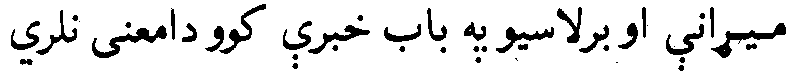

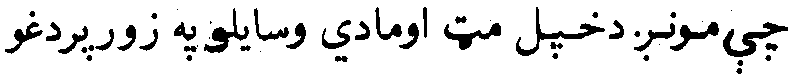

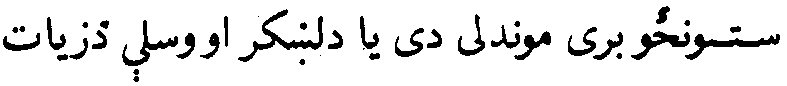

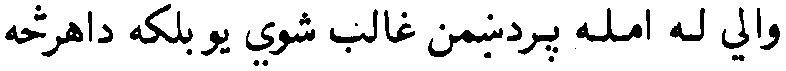

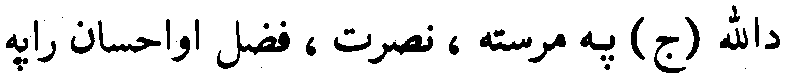
برخه شو يدي ددي عقيدي اوسبيخلي احساس بيه 
رنهاكي بـ مونب. هيخغ كله ديو وينبته بِ اندازه ددغه

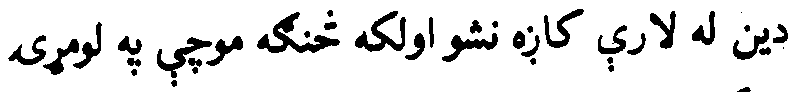

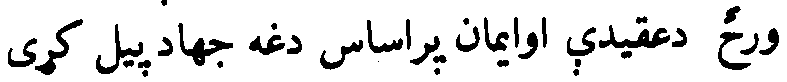
دى يه آينده كي به مم داسوجه اسلامي جهاد وي اومـونبز بـه بي داصالت ساتنه كوو او بِ ميخخ قيمت

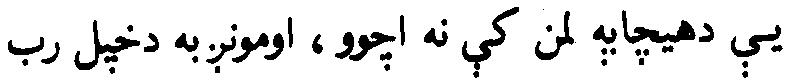
يه سيخه لاره مخ به وراندي روان يو مهفه نه توفيت غوالهو 6 جبرهــه مـوتوكل دى هغه ريربنه كارماز

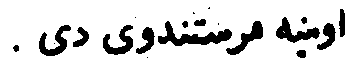

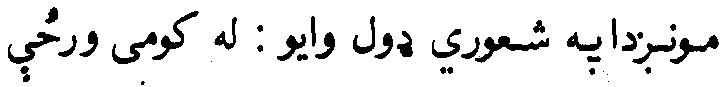

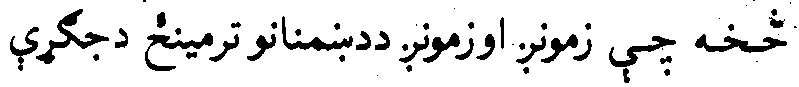

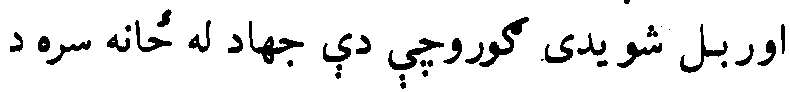

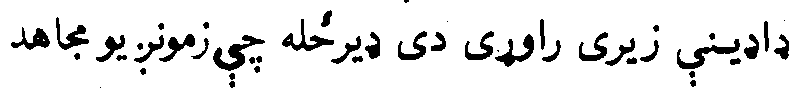
دجــلك بـه دكىركي شهـيد شو يدى دهغه له ياكو

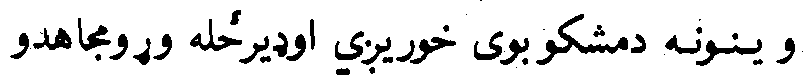


كرو يبرنسو ددنبـمن سترو قواو ته ناتي وركري :جي

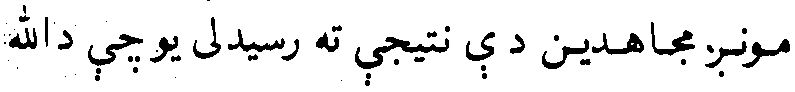
تعـالى تـائيد له مونزسره مل دى اورب العزت جلت. عظــته به ددي جهاد به بركت مونب. اوتول محمدي امست ته سرلوي اوسعادت به نصيب كري . رإنشاء. . للإ

ترتوبوري :جب مونب ددغب كلكي عقيدي به رناكي خبّل جهاد ته دوام وركوو دكافرانو دشمير اوجنكي تجهـيزاتو زياتوالى به مونزته خه زيان ونه ثي رسولى حُكه :جى الله تعالى له دوى نه بيزاردى ، اوله جانه جي الله جل جلاله بيزار وي هغه جير زر له نابودى

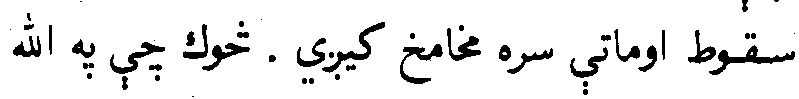

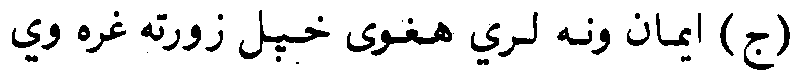

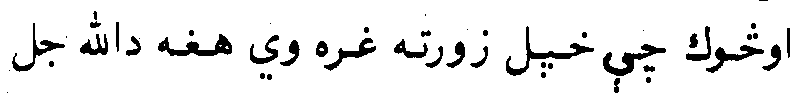
جلاله له. مرستي نه يمحوم وي . 
كَه مونبر لبريوخوالله (ج) راسره مل دى له باسره

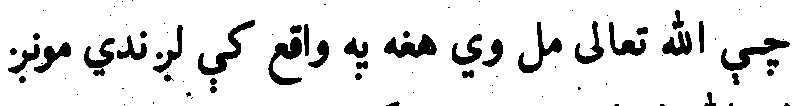

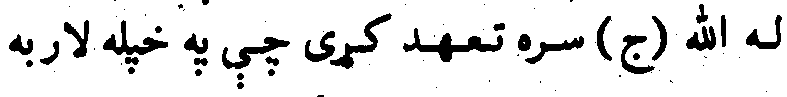

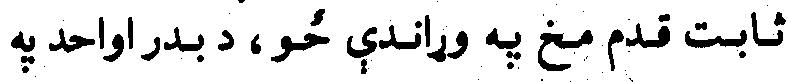

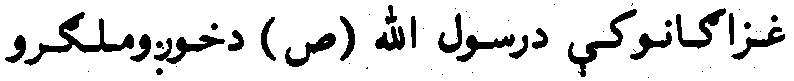

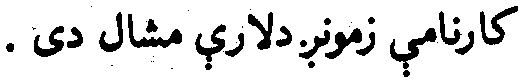

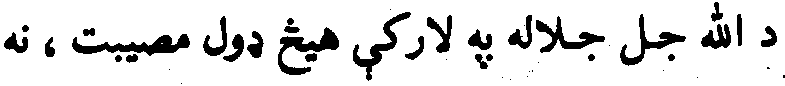

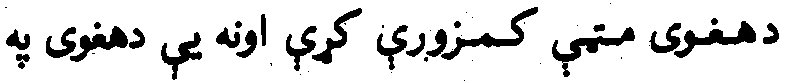

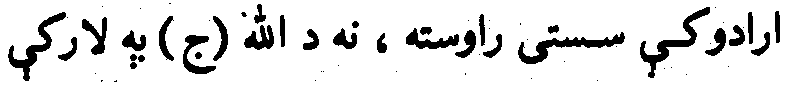

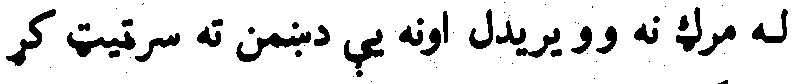
( ) وكاي من نبي قاتل معه ربيون كثير فها ومنوا

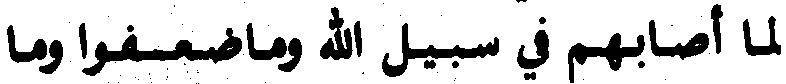

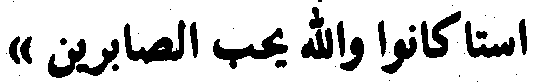

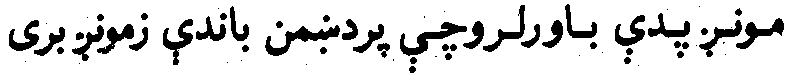

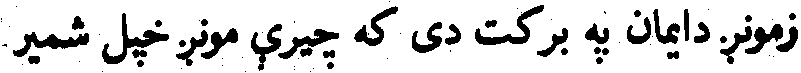




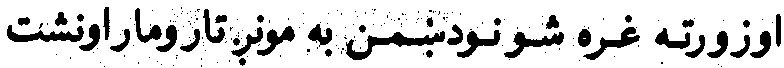

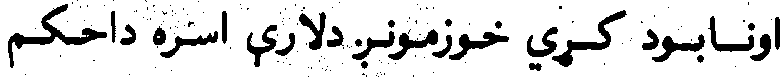
الحاكمين درباردي له هغه نه دنصرت غوبنتينه كورو

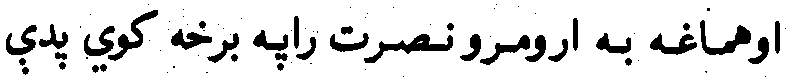

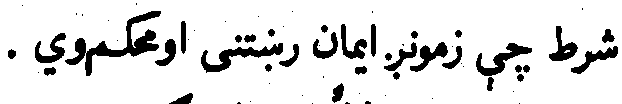

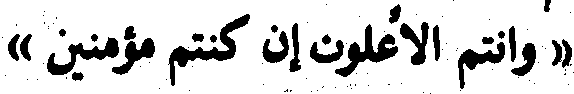

\section{ورونهن 1}

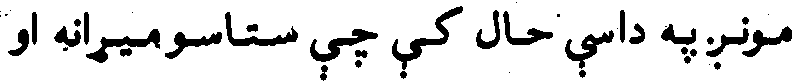

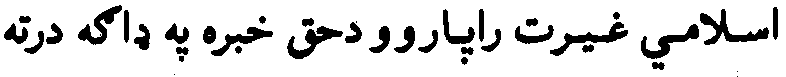

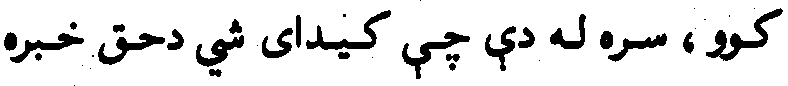

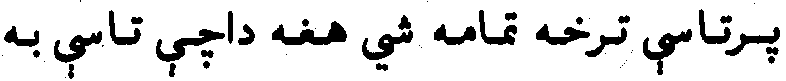

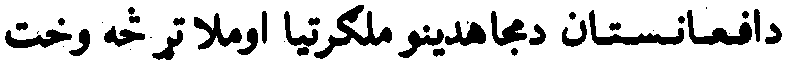
بيل كوى او دمهاجرينو كونلو ، يتيمانو ، معيو بينو

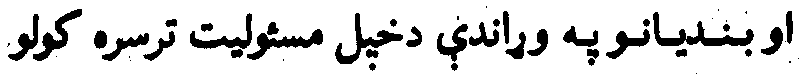

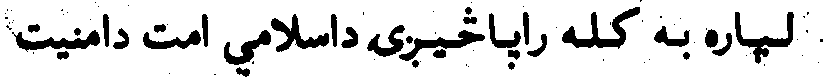




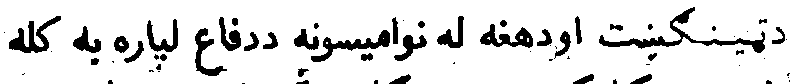

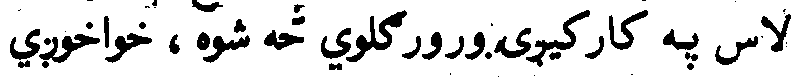

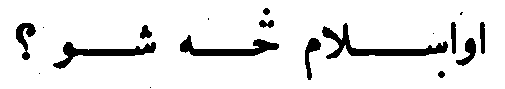

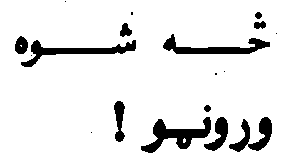

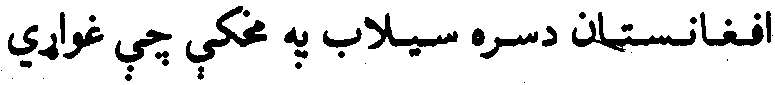
اسـلامي امت به يخه وانلي يوبوخ بند دى ددي بند

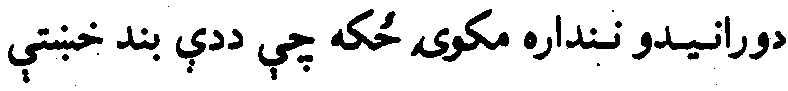

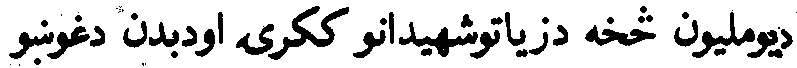
بوتى دي ددي بــند بياودانول خه آسان كارنه دى دي

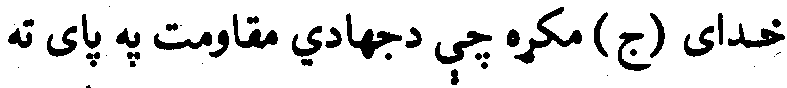
رسيدوسره دغه بند ونيويزي نو افغانانوخوبه دالله جل

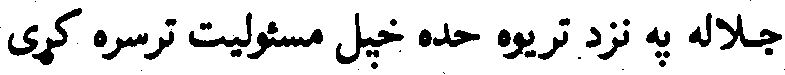

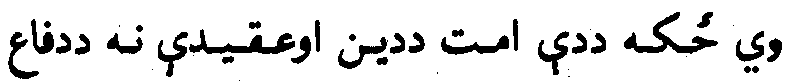

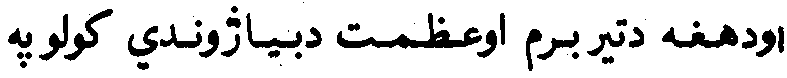
لاركي يس ميخخ شيى ونه سبمول ـ خو له افغانستان 
ثخخه وروسته به به نودوخه حالت رامجي ؟ سيلاب

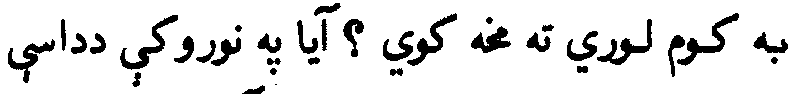

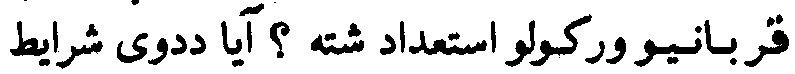
اوطبيعي ، سـتراتيزيكي ، اجتماعي اوسياسي

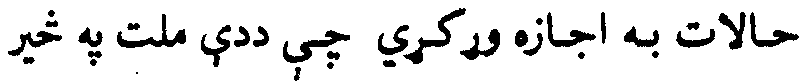
بِاخون اومقـاومـت وكري ؟ اجازه راكرى ووايم

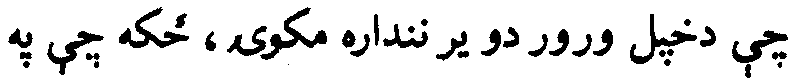

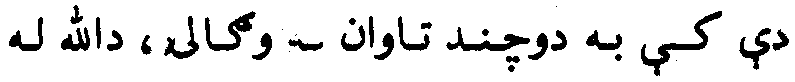

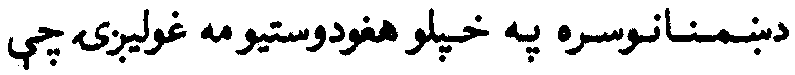

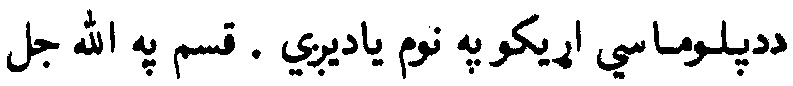

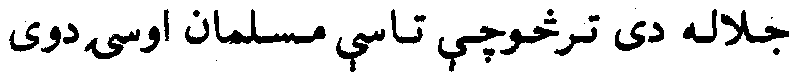

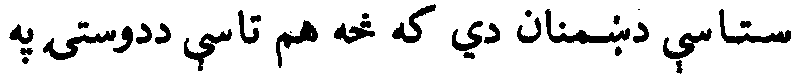

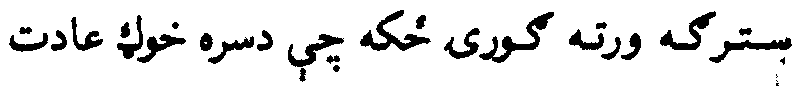

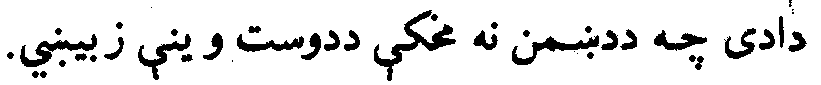

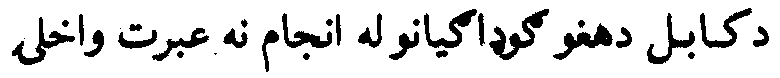


جي كلمونه كلفونه يب د كمـونسيزم غلامي وكره اومكافات يب له بي شرمانه وزل كيدونه يرته نورنهه

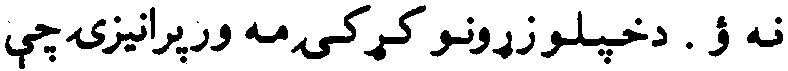

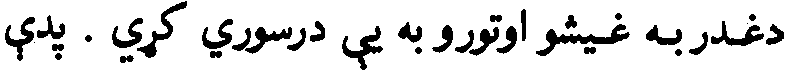

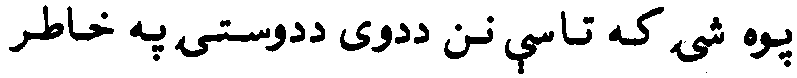

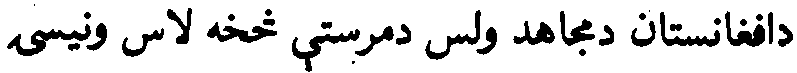
ددي و يره شته جبي سباووايح بحي مونبز به مغه ورنُ

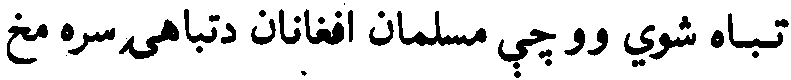

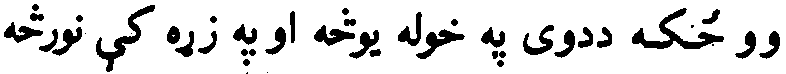

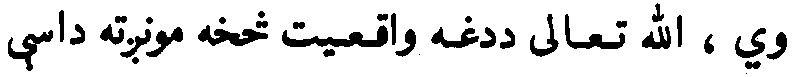
خبر راكرى دى : ( كيف قإن يظهروا عليكم لا لا يرقبوا فيكم الا ولاذمة يرضونكم بأفرامهم وتأبى

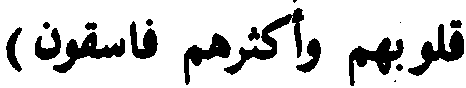

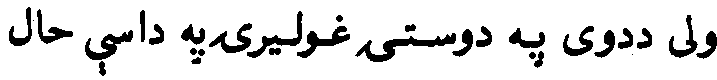
كئ :جي كه ددوى لاس برتاسي برشي نوبه ستاسي 
به باب نه دوستى ته وكوري اونه معامدي ته ، تش

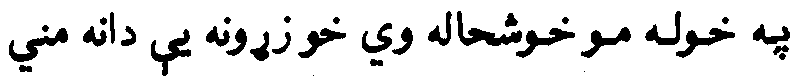
اودوى زياتره سرغروونكي نافرمانه دي ).

كوم خللك جبي روسي ملـحدانوته بِ خجيله خاوره

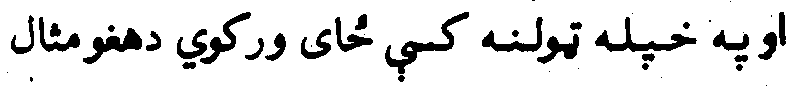
دمنه جابه خيردى جي يه خجيل لستوني كي ماران

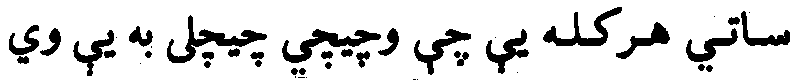

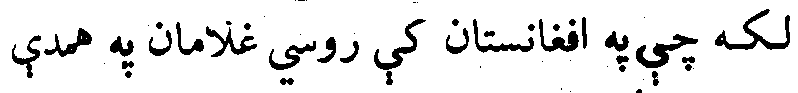
سرنوشت أختهه شُول .

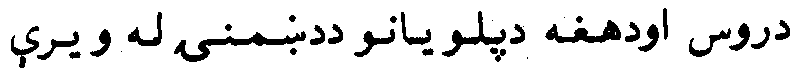

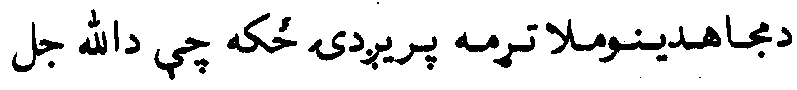

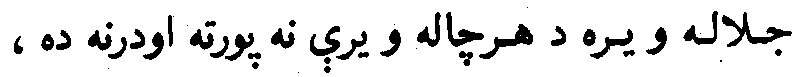

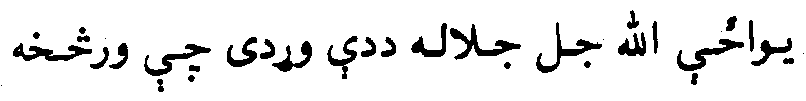
وو يريرى. 
((اتخشيونهم ؟ فاللة أحقى أن تخشوه إن كنتم

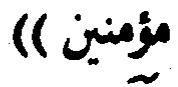

(آياله كافرانوختخه و يريرى ؟ يواسُجي الشج جل

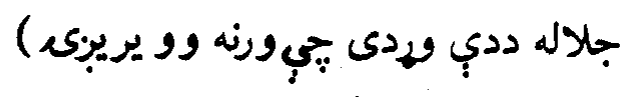

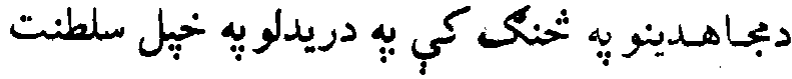

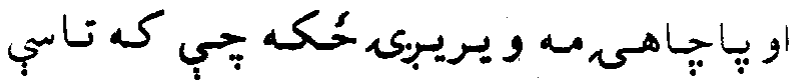

دبجاهدينوملا تروكيى نومالك والك الملك ذات به ستأسي

() قل القّم مالك الملك تؤنى الملك من تشاء

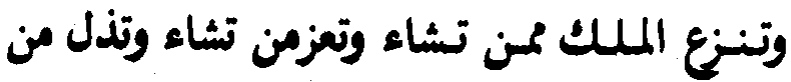
تشاء بيدك الخير إنك على كل شيء قدير) ). ( ووايه اي بيغمبره ! المى دسلطنت خحاونده ! جاته

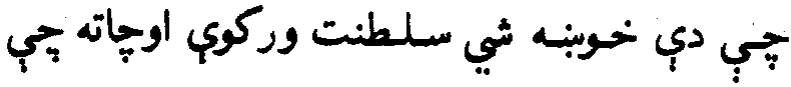

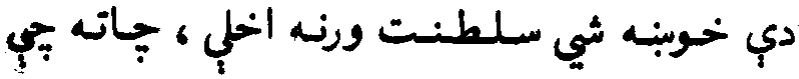
دنسوبنه شي عزت وركوي اوجاته جي دخوبنه شي 
ذلت ورته بِ برخه كوي خيربنيكنه ستايه لاس كي

$$
\text { ده ته به مرثي باندي قادريي ) نوبه }
$$

نوله بـاهدينوسره بِ ملا تركولوسره به ستاسى

$$
\text { عزت اوسلطنت لا قايم شي • }
$$

تركومسه حمايه جي يه مونب. اره لري مونبوله الله جل

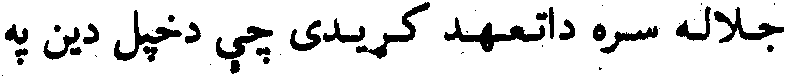

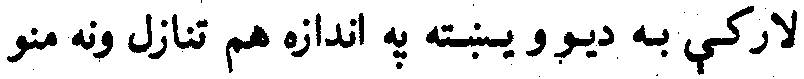
اونه به ددي فرصت دبنمن ته وركروبي خبيلي بينب

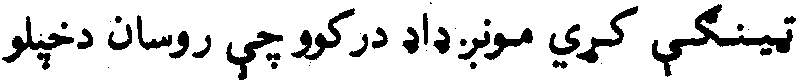
تولوجنكي تجهيزاتوسره سبره مخ به سقوط اودماتي بي دوني

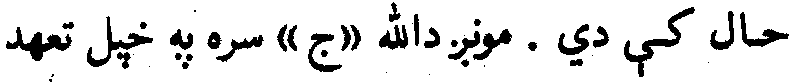

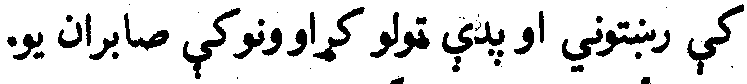

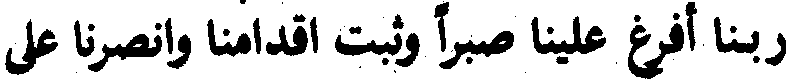
القوم الكافرين. مكرتـاسي ته مـم دايكـارده يجّي دخبلو بجاهدينو 


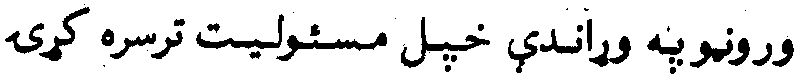

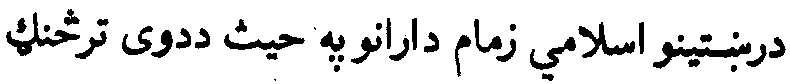

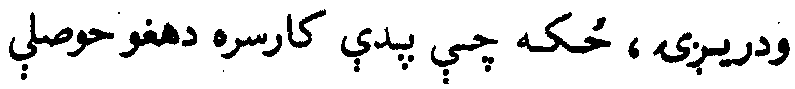
اومورال لوريبي .

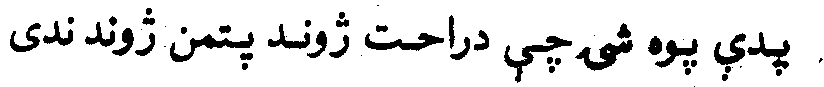

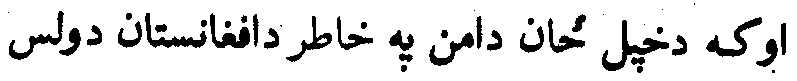

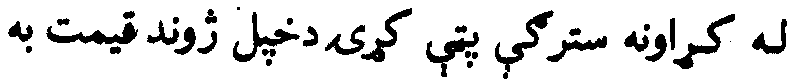

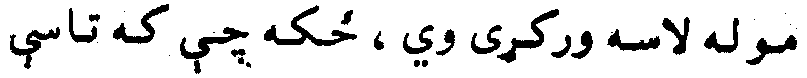
اسلامسي زونسد غوارى نو كافران به مينخ كله تاسي

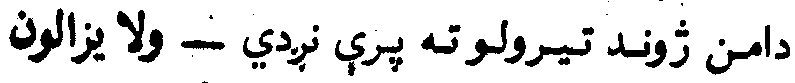
يقاتلونكم حتى يردوكم عن دينكم أن استطاعوا. ( اودوى به ترمنه درسره.جنكيري ترخوجي تاسي

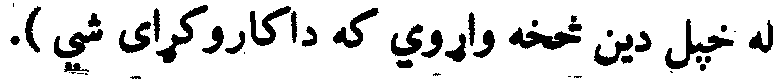

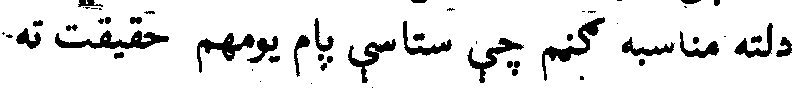
$r$ : 
راوكرئموم اوهنه دادى جيب دافغانسستان جنك دمادي انكيزي به بــا ددوو ولسونو ترمينحُ ندى بيل داونيل

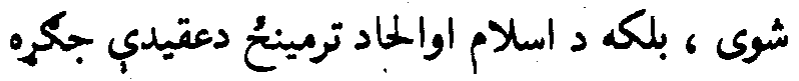
. os

دادهـغو اسـلامى غزواتو سلسله ده يجي داسلام ستر تايـد محمد صلى الله عليه وسلم بيل كريده ـ ـ اومونب.

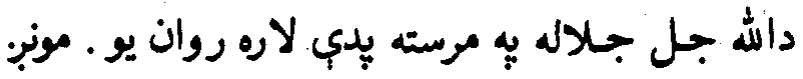

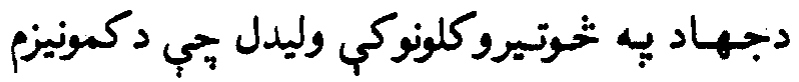

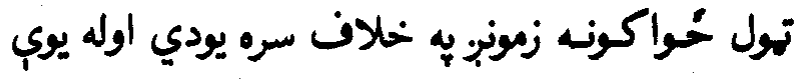

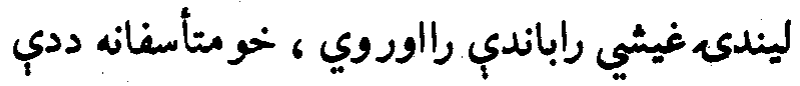

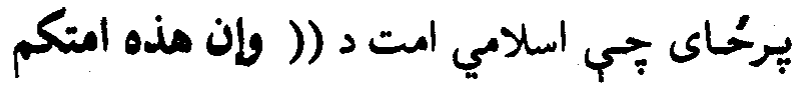

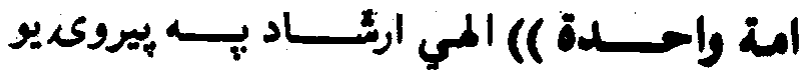

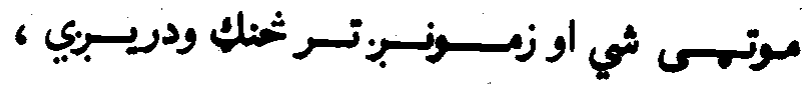

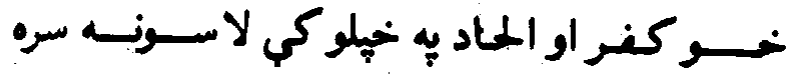

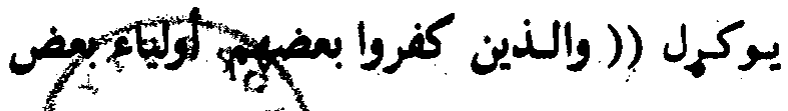
$\left(1,0 n^{n}\right)$ ri 
الاتفعلوه تكن فتنة في الأ رض وفساد كبر)) كانران عحينـي دحُينو نودو دوستان دي كه تاسي

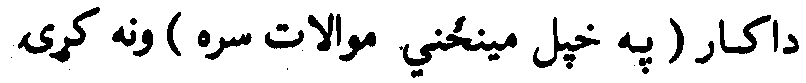

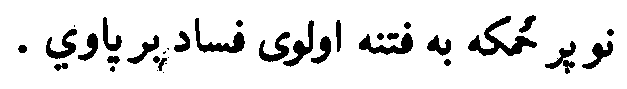

\section{ورونهو!}

تاريخ كواه دى:اسـلامي امت لكه ديوي كونى

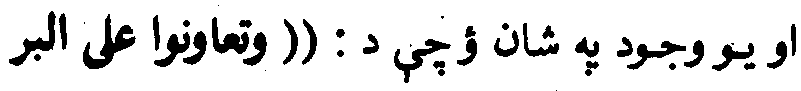

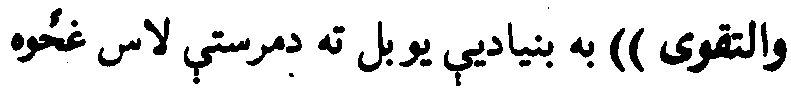

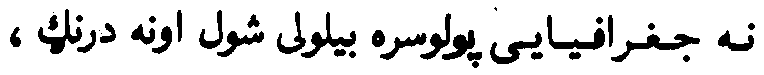

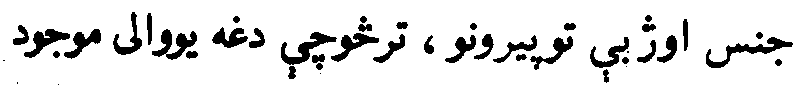

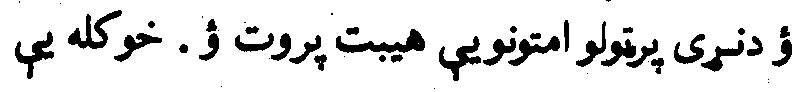
جي دوحدت كري وشكيده نود كراو ونو اومصيبتونو

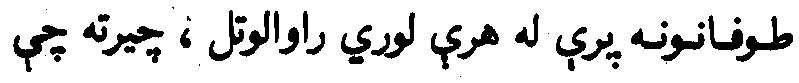

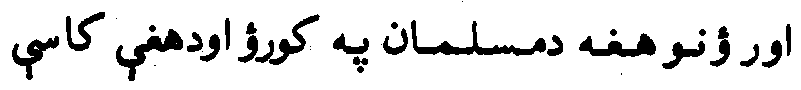

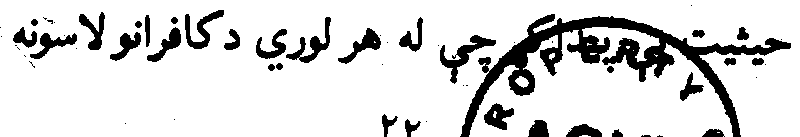
$\operatorname{rr}{ }^{\star} A C K$ 


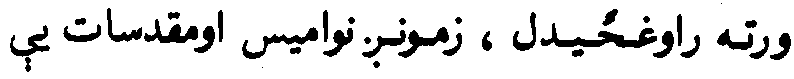

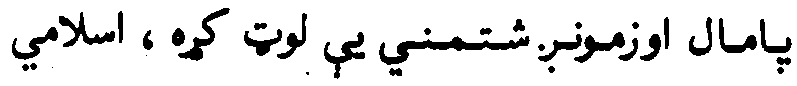

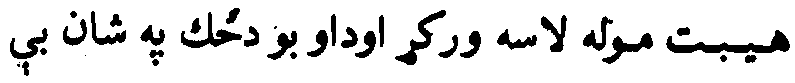

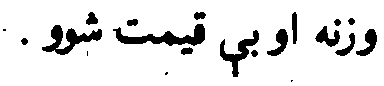

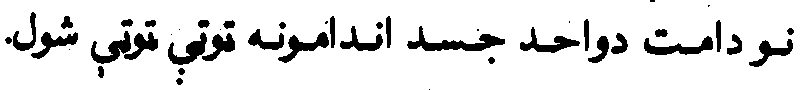

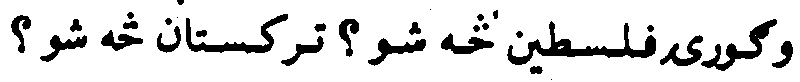
از بـكســــان اودمـاوراء النـهر نور اسلامى ملكونه اواندلس خه شو ؟ . رب وامعتصهـاه أنطلقت ملء أفراه الصبايا اليتم أنمات لا مسنت أسمـاعهم لكنها

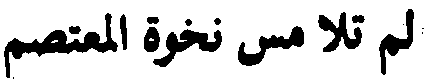

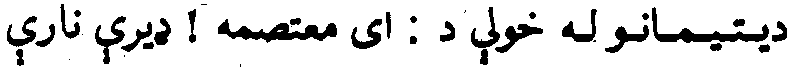

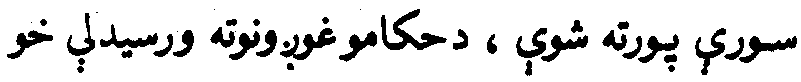
دمتصم غيرت يب ونه مونله . 


\section{ورونهو!}

زه دخجبل مسئوليت له غخى تاسي ته دز ه لكومب

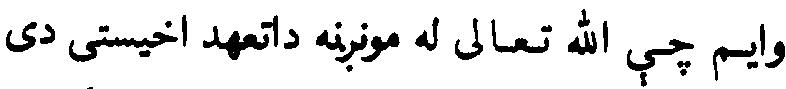

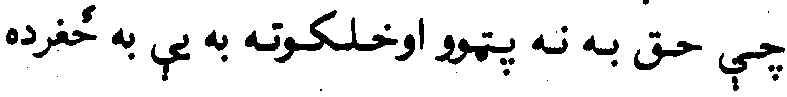

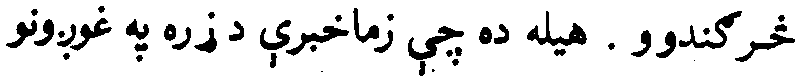

واورى ، زه تاسو دافغانستان د بجامدينو اومهاجرينو

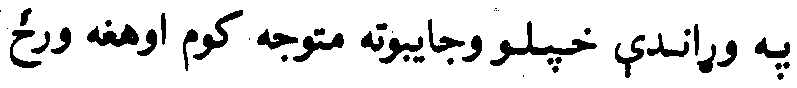

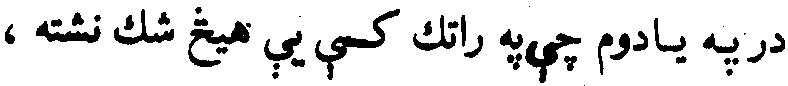

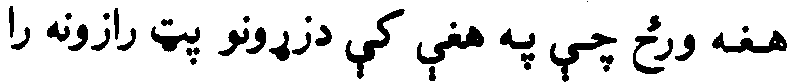

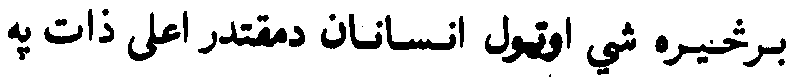

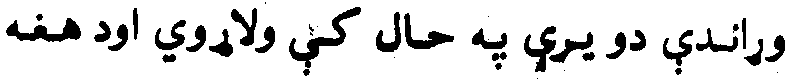

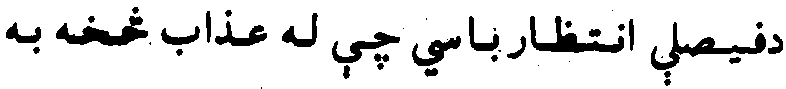

و يريزي اود رمت به يب هيله من وي نوددفه دين

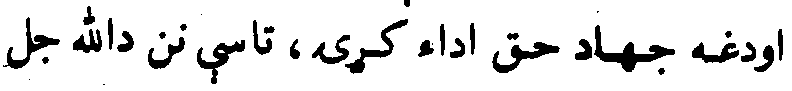

جلاله يه وراندب دهنه د بندكانوبه باب مسئول 
يسى ، د الله خخلـوق ته دالله كلام واوروىى، اودهنه له غخلوق سـره ممدردي وكرى ، دنهيلو اسلانوله فنـاكيلونه عبرت واخلفيجي مغوى يرون بيرته وو

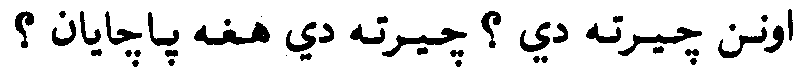

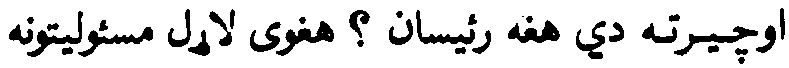

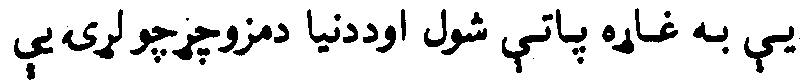

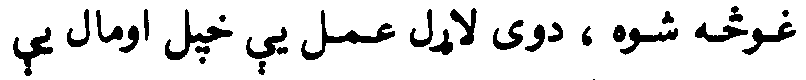

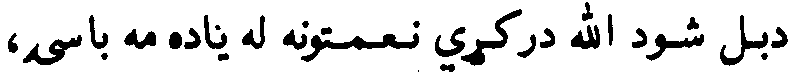

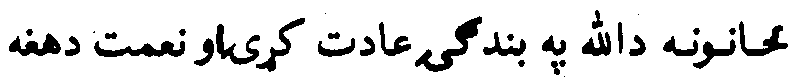
له زوال نحخه مغكي غنيمت وكنى ديكه ناشبكري دنعمت دزوال لوى عامل دى . مهدا اوس موجي فرصت به لاس كي دى ، درّوند

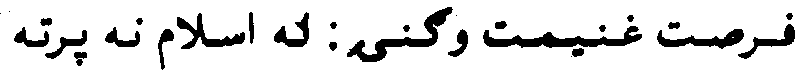
يرمسلمانانو بل نظام مه حاكم كوى اومه يب دعدل

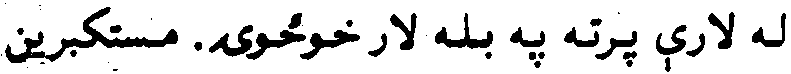




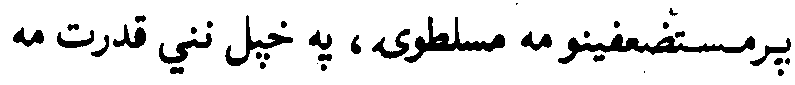
نـازيسبى بـلكه راتلـونكي ورعٌ به نظركي ولركهيّ

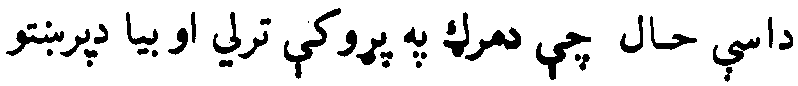

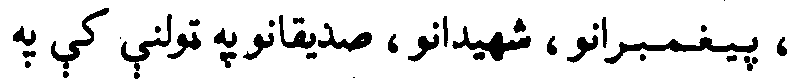
داسي حسال كي بـ دقهارالله ("ج) ) به حضور كي ولاريسى جـي دا ترل انسـانـان بـه هيسبت وهلي اووارنطاء وي اود ظالمانوغزنه به توروي . 1 iss

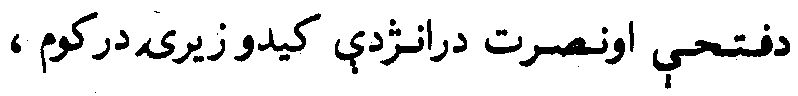
داده اوبمى تجي دغه طاغوتي حُواكونه :جب نن دنرى مستضشفــان تهـديده وي ديانكي مادي وسايلو

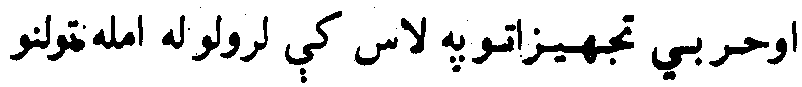

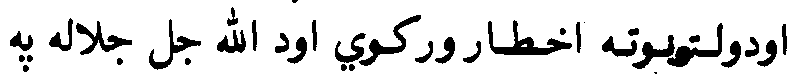
عللوق بـانـدي نساروا فشـاراجـوي دالله جل جلاله

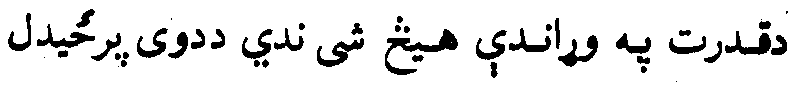


اونسكوريدل لري مه كنم تاريخ ددغه حقيت كواه

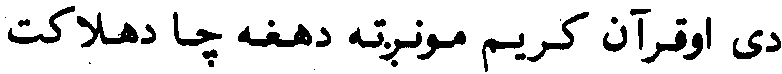

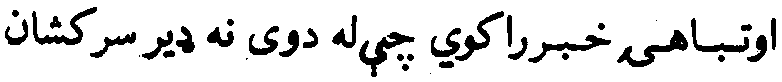

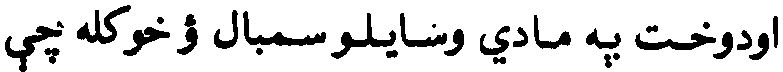
دسركثى اوانحـراف اوج ته ورسيـدل نوالله جل وديل

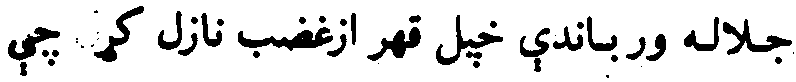
بيإجدتينتي اوخلاصون لارنه موندله .

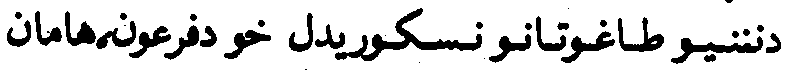

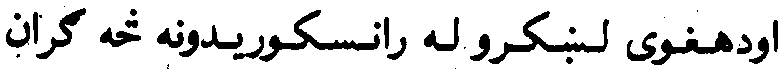
كارندى (( الم تركيف فمل ربك بعاد ارم ذات العماد التي لم ينلق مثلها في البلاد )).

آيا تاونه ليدل يب ستاجرورد كار دمتنو جاوندانو عاد

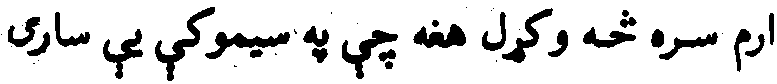

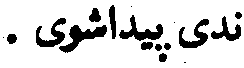




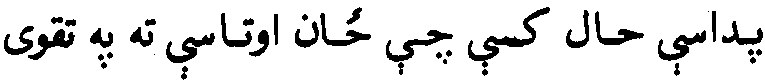

توصيه كوم حُكه يجي تقوى دستونحُو دحل كلى دهي

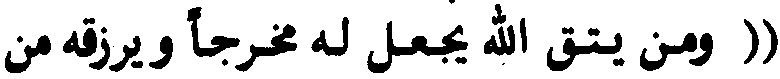

\section{حيث لا يتسب ()).}

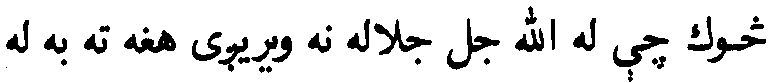
تنـكسب نه دوتلولاره جونه كري اوله داسي مدركه

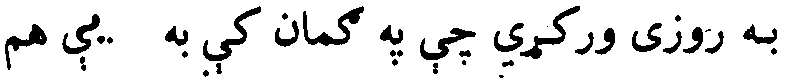

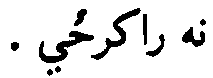

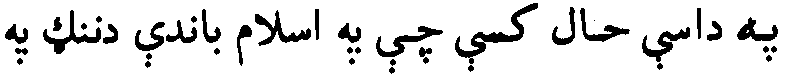

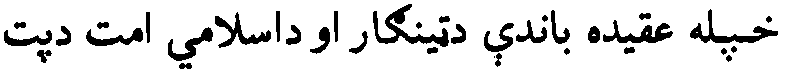

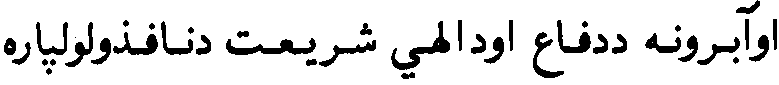

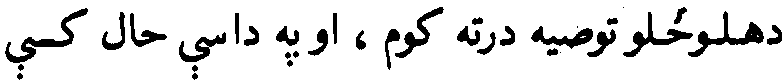
جي دجهاد دفريضي دبيا زوندي كولو لياره دمتو رانغنتيلو توصيه درته كوم هغه بِّب ستاسي دلوشيان 
اودرنسبـــت تضضمين كَوي اوتير برم اوعظمت موبيا

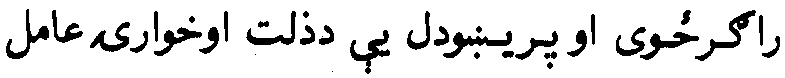
دي نوددي لاندي تكوييشنهاد كوم :

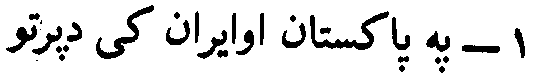

مـهاجرو ديالنى خواته ستاسب يام را اروم ، هغوى

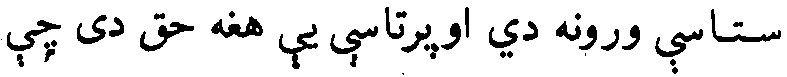

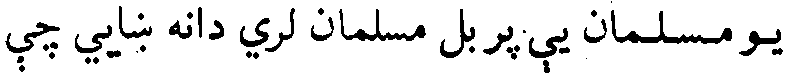

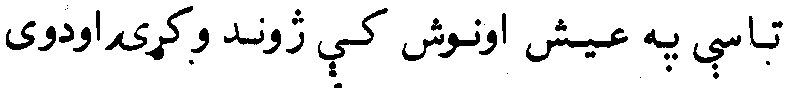

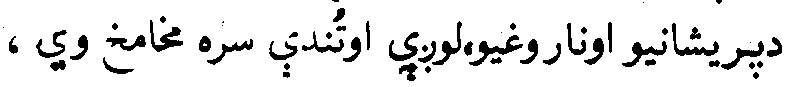

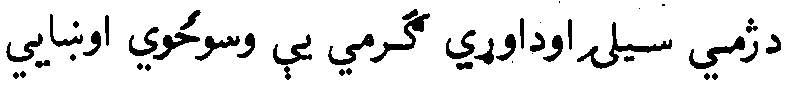

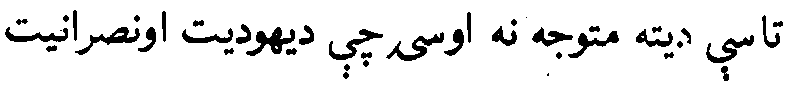

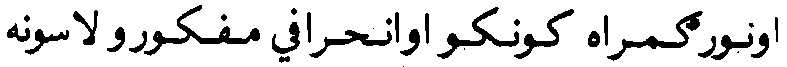

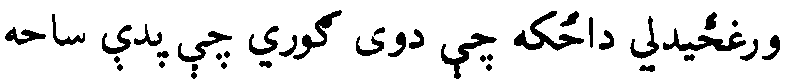

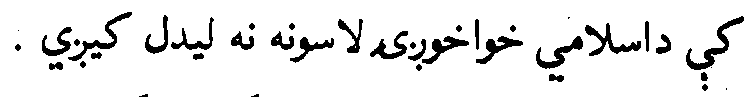

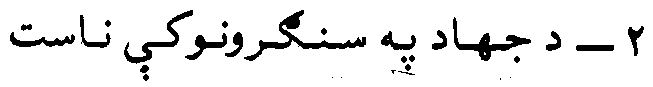


بحاهـديس مـه ميروى اودرسول اكرم صلى الله عليه

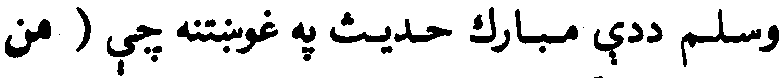

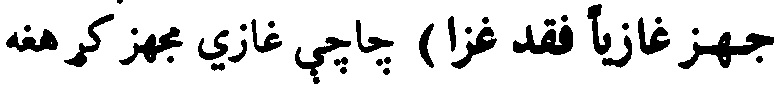

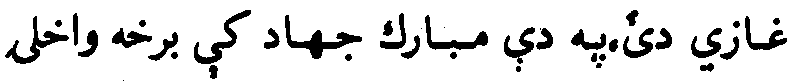

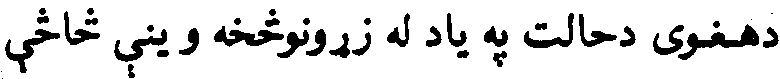

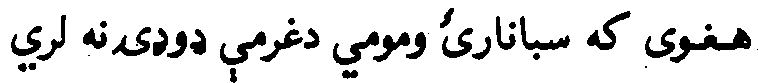

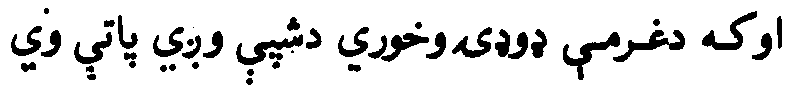

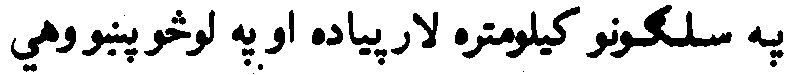

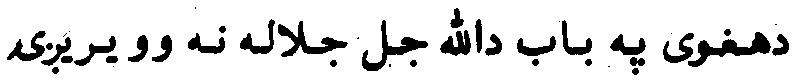
اودمــوى به باب به دقيامت بِ ورجُ دالله بِ حضور كسب درنه يونبتنه وثي .

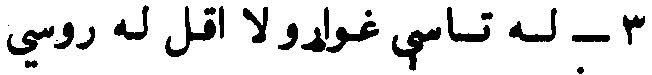

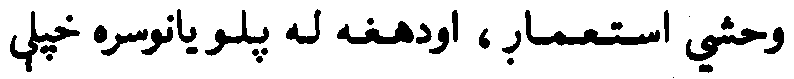

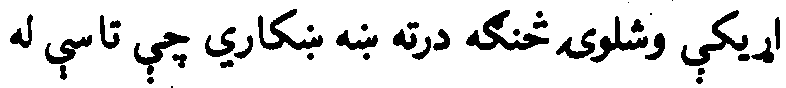

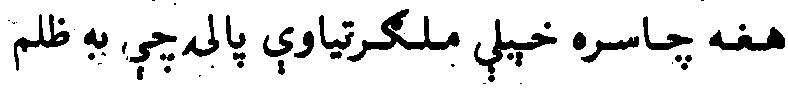
$\mu$. 
اوتيري سره يج ستاسب داسلامي وطن ويريوي برخي

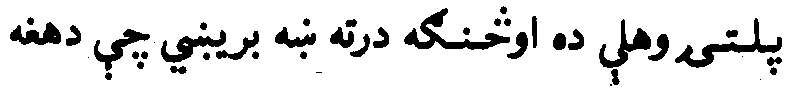
جـاسـره بِلاس روغبه وكرى جهي مغوى دينجونه منتاسو دورونو مري و ينب ثخاخي الله تعالى فرمانيلي () (ياايها الذين T منوا الا تتخذوا الكافرين أولياء من دون المؤمنين أتريلون أن تمعلوا الله عليكم

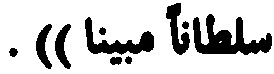

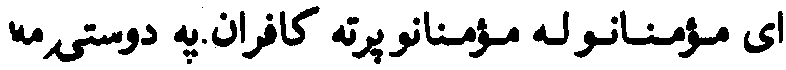
نـيسى آيـا غوإدى بِرخبـل حُّان داله تعالى دالزام خركند حجت برابركري به بل كاى كيلفرمائيل دي :

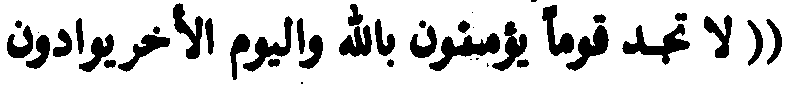

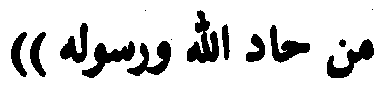

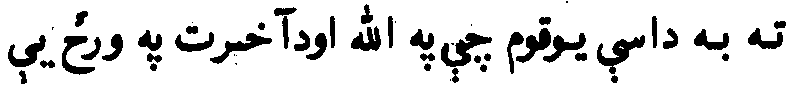
ايـان وي له مغه باسره دوستي كونكي ونه مومب M 


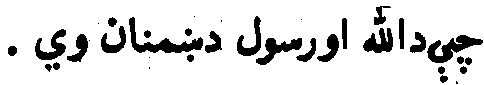

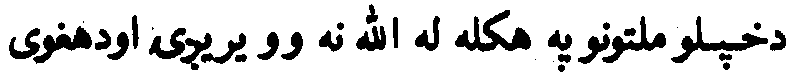

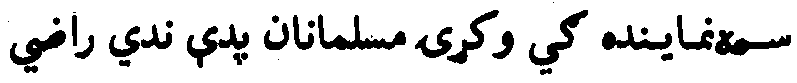
يجي تاسي به افغانستان كي متابي به وردي ورونوباندي

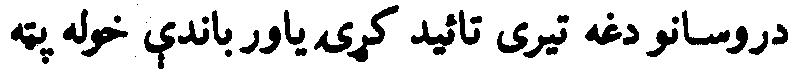

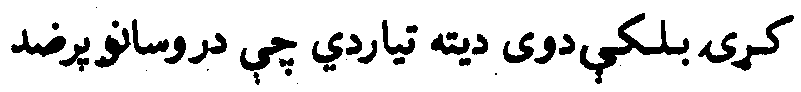

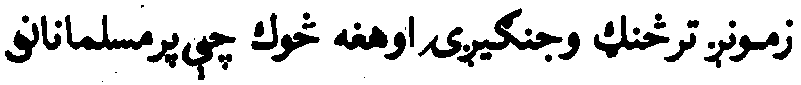
باندي دكافرانو دتيري ملا تهر كوي مغه له يوي خوا يه دي دنياكي ؛ه خجيلوملتونوكي ذنجيل موجوديت

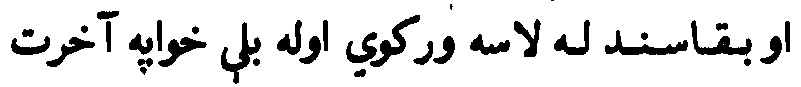
كى داله دمخستب مواخذي و يره ورباندي ده الله

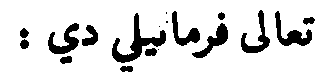
(( ولا تركنوا الل الذين ظلموا فتمسكم النار)) ع - غوالدو مونبو دافغانستان دمسلمان ملت rr 


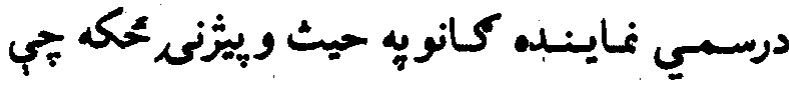

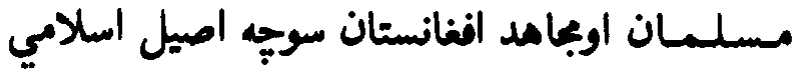

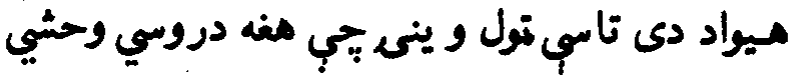

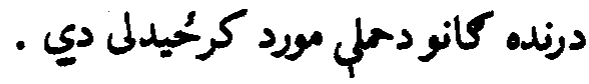

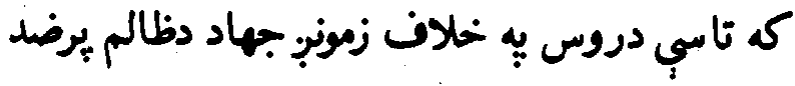

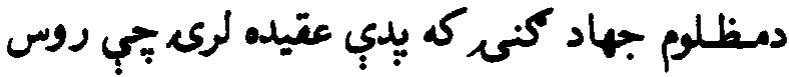

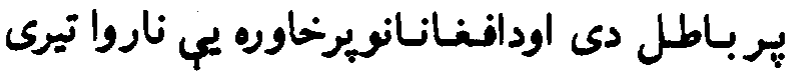
كريدى اوداقتدار به خغركى بِ مسبي كسان كينولي جسى مغنوى اصلا اففانان نشي كنل كيداى نوبيا.

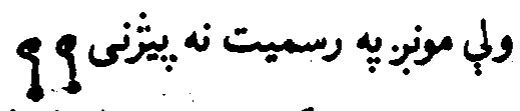
له ويسرو كلونور رابديغا د افغانستان د نمايندكى

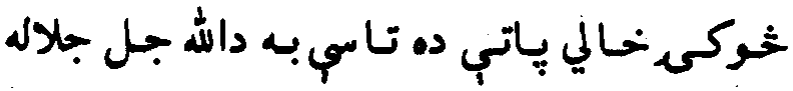

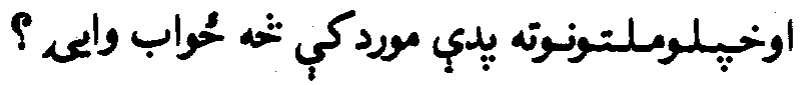

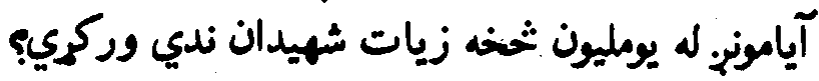

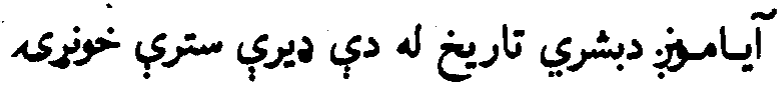
$\mathrm{rr}$ 


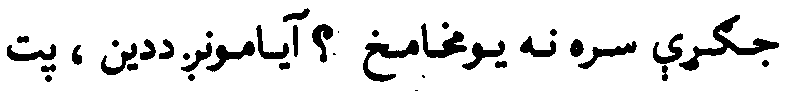

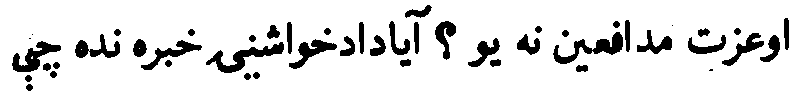

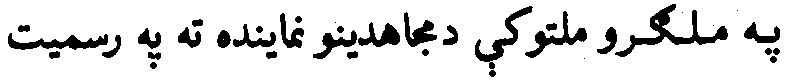

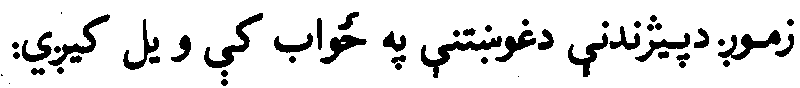

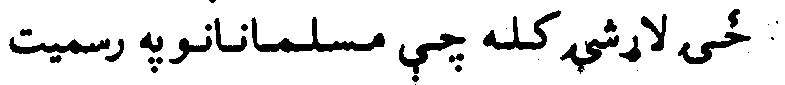

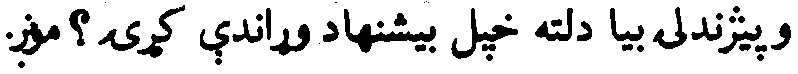
خهوبيدي عقيده وو بِي تاسو به به بين المللى غونلو

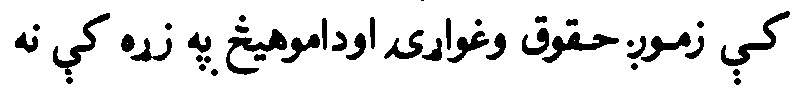

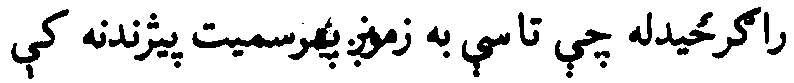
درنكك وكرى مكرددي لبـاره إجب تهول نهريوال

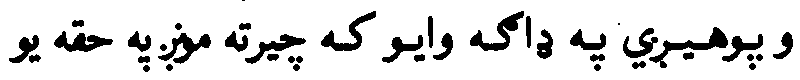
نوحق به خبيل حُاى ونيسي اوحُان به يرخلكووييزني

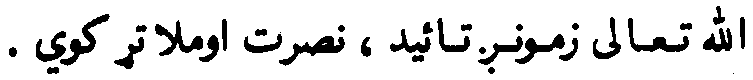
مغه دصالمر بند كانو ملكرى دى به رسميت سره

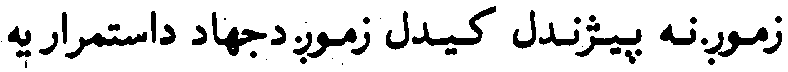




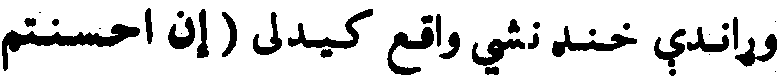
احسنتم لأنفسكم وإن اسأبم فلها ). كه تاسي بنه كوى بنيكنه ستا سب دنبيل لحمان ده

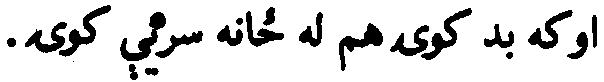

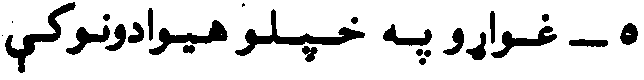
دبجامدينولياره رسمي دنترونه يرانيزى ترثخو دمنوى

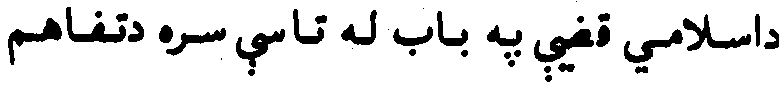
اواسلامي تولنـوته دجهـاد دخهبرونو اود بجاهدينو دحالا توديرله بسب خحركنديدو زمينه برابره شي .

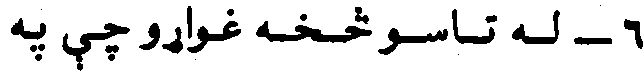
روسانو باندي به نزيواله سطحه به اقتصادي سيا سي

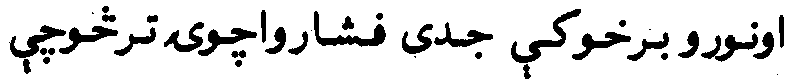

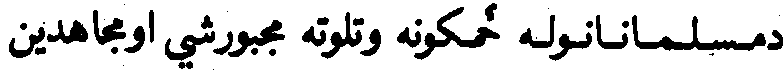

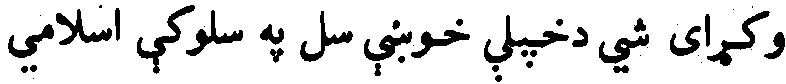

$$
\text { حكومت قايم كري : . }
$$


- V داغـوبنـتـنه كووجي يرهغه شي قانع

ششى ببركوم جبي دحت خـاونسدان يعنبي بماهدين

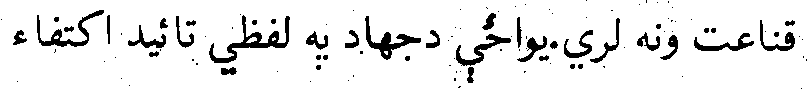

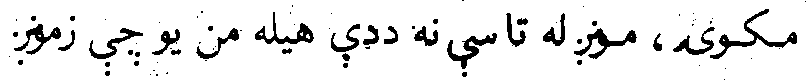

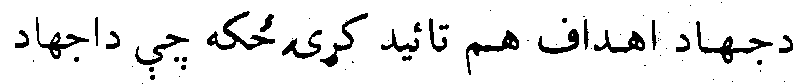

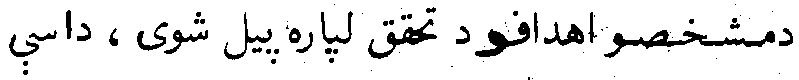

ونه شبي :جب ستاسو ياستاسو دحُينومواقفوله امله زمجز

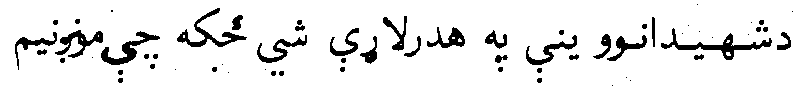

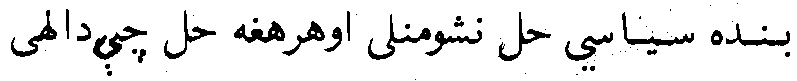
حكومست دجبريدو متضمن نه وي يه كلكه غندو

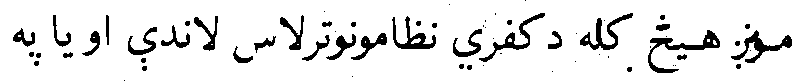

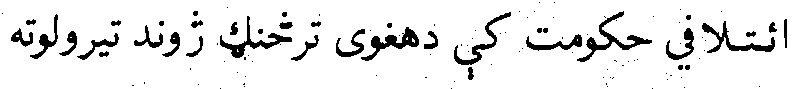

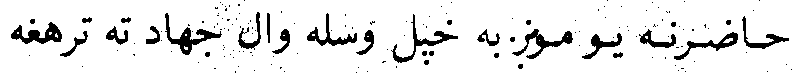

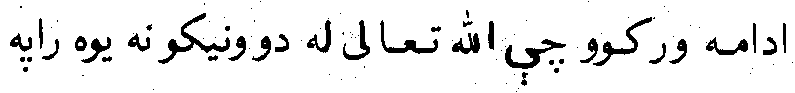
برخه كري يافتحه ياشهادت.تاسي هغه حل ته غاره 
مه زدى :جي د منه به نتيجه كي دروس له وتلونه

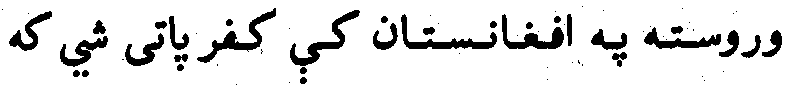
داكارمسو وكر نـوتاسي به له بهاد ، نهيلو عانونواو.

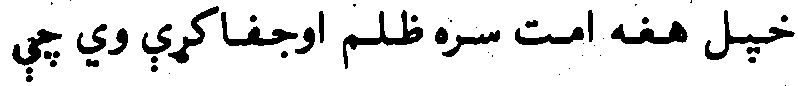
دبنمنان ورته به كمين كي ناست دي . 1- بـ اسلامبي اوبن المللن غونلهوكي دافغنانسـتـان دقفي دمطرح كيدو يه وخت كي يسوازي دخولي به غنـدنه اكماءكول. كوم درد نشي دواكولى اونـ داد اسلامى مروت اوميراني لارده 6 بلكي داقضيه دالله جل جلاكل له امرسره سم دجدي اوعمليّي اقدام غوبنتونكي ده .

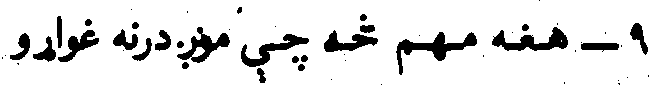
دادى كله :حي تاسي دافغانستان د قهي يه باب فكر او يريكري كوى دالاندي امس بيه نظركي

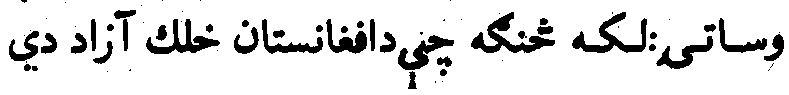
rV 
اومســـــل اسـلامي شـخــيت لري دنيل هيواد

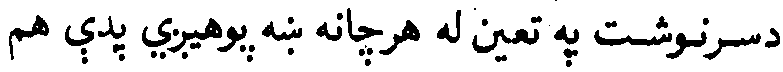

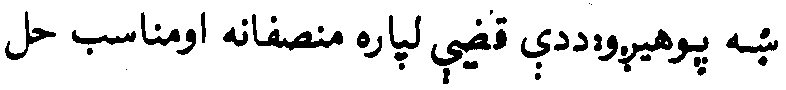

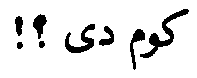

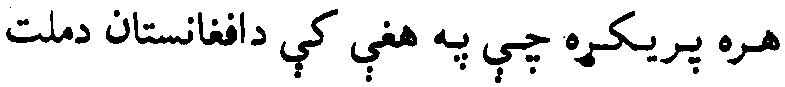
دارادي يـرخلاف تجي جهادي قوتونه يب تمثيل كوي

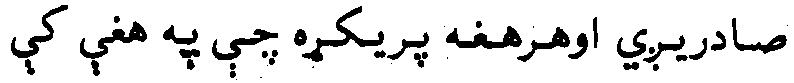

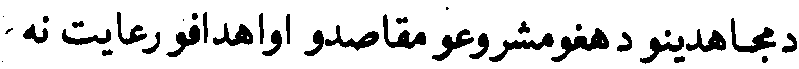
وي شـوى تجي د مهود دتمقت لِياره جهاد كوي لكه

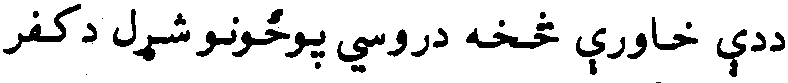
اوالملاد دأكارو ميوه كول او داسلامي راشد حكومت

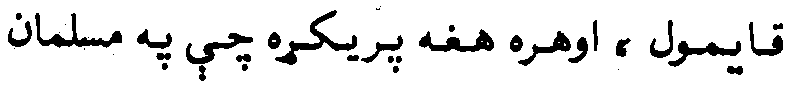
افنـانســـان كي دكفري رُزيمونو دبقاتضمين كوي هغه دمجاهدينولياره دمنلو ورنده بلكي داد افغانستان دحريست اواسـتفلكل بـرمبن يوه سخته خبره كنل 
كيبزي.روسانو جيجيدي بِوروستيو وختونوكي دنجبل مزدور اوغلام نسجيب بِ خوله داور بند ، ملي سولي

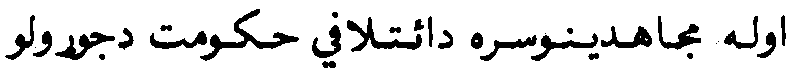
هنسووري شروع كري دي م دامرخهم دهغودسيسو.

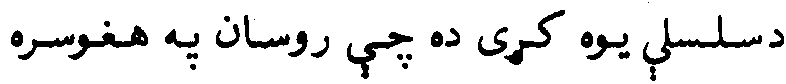

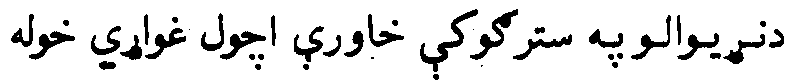

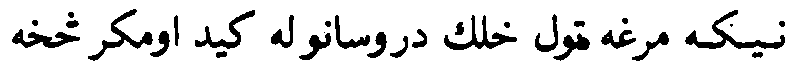

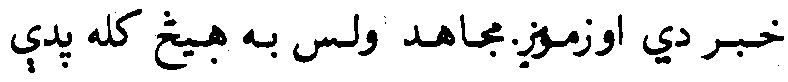
دسيسو اوجلول تيرنوحُي اونجبل مقدس جهاد ته به به به بهي

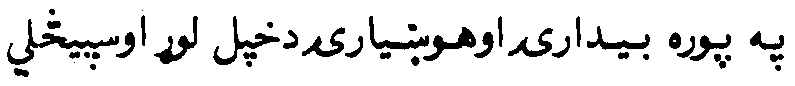

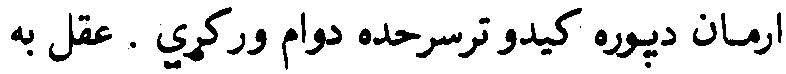

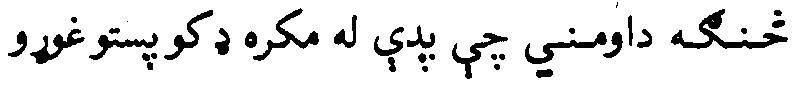

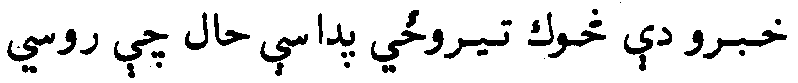

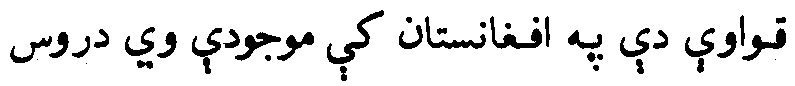
لاس بيوخى ملحد كمونست رزيم رانسكورشوى نه 
وي أوتول هـنه عـوامل دي نه يواحُي ديخوابه شان بِاتب بـلكي زيّيات شوي وي لكه كفري اوالحلادي حسكومست ، ديرديو يرغل اودمسلمان ملت دخوبني

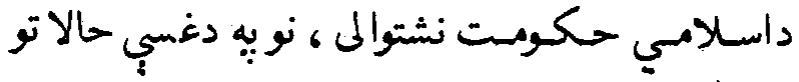
اوشرائطوكي ددغوتولوقر بانيو وركولوسره سره ددغه

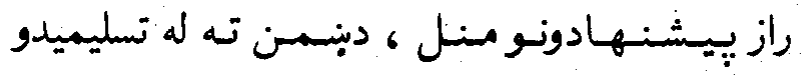

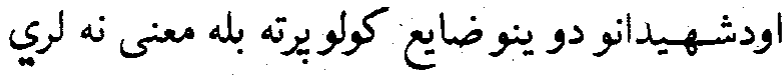

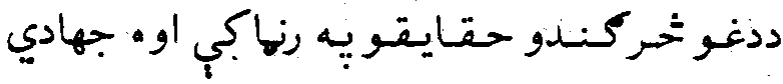

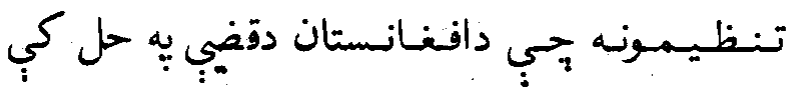

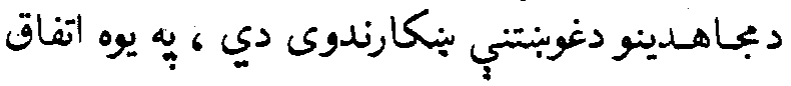
سره دالاندي يريكره صادره وي :

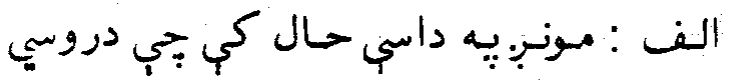
قواؤيه بـشبهره توكه فوري او بي قيد اوشرطه وتل

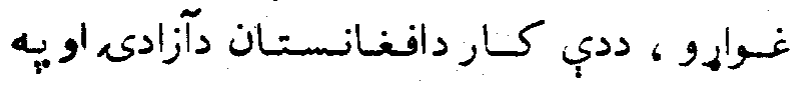
افغـانسـتـان كي داسلامي حكومت دقايميدو لِياه 
وسله وال جهاد له دوام خحخه يرته بله لاره ته وه. ب : دروسي تواؤله وتلو اودكفري اومزدور

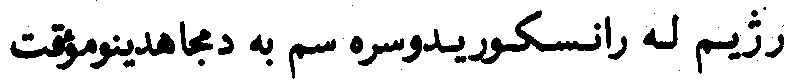
حكومت دنجل ميواد ن واكي به لاس كسي نيسي. ج : ددي مـوتَت حسكومت ترثخارني لاندي به

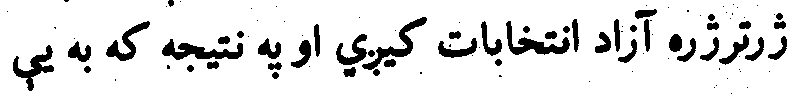
اسلامي شورئ اواسلامي منتخب حكومت مينُ ته

$$
\text { راحُي. }
$$

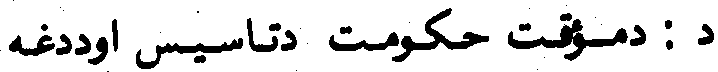

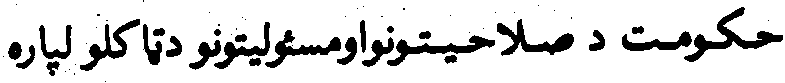
دلوائحسوجدولو اوطرحي وراندي كولو به غرضن

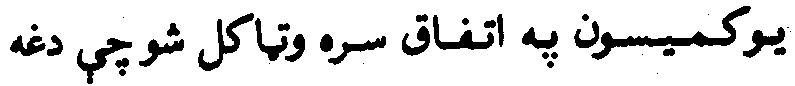
كميسون دروان كال دفروري له لومرنيو ورجوخهخه

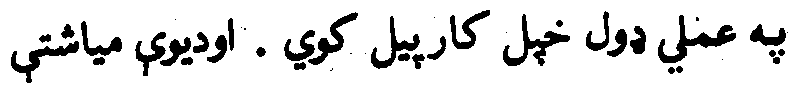


يه موده كي به خـبله مسوده تكميل اودمباحثبي

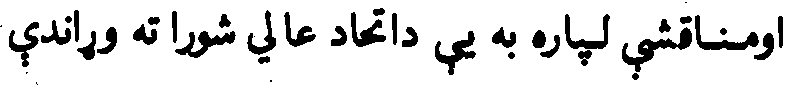
كوي •

: ديومقتدر او باصلاحيته قضاتي كميسون :

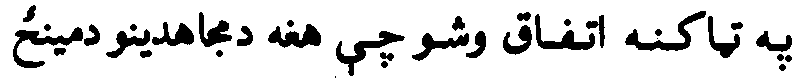
شخري فيصله كوي او بدي مورد كي شرعي فتواوي

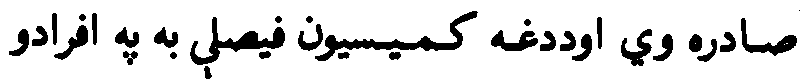

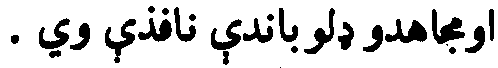
و : دمـــــخبي شورى له تشكيليدوسره سم به وله

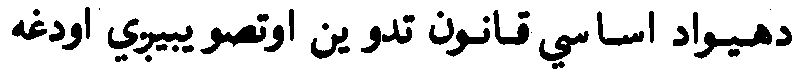

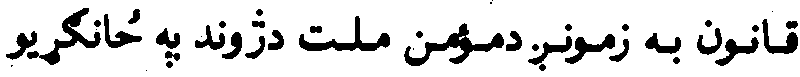
اوتولنـــزو تولو ساحوكي به بشبره توكه د اسلامي

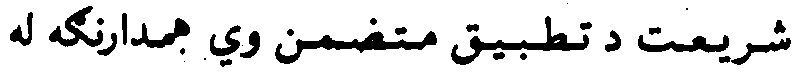

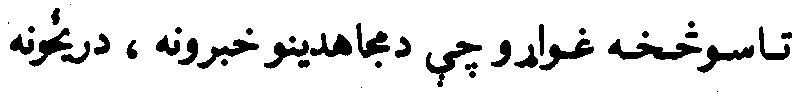

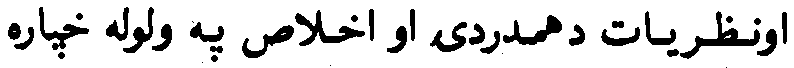


كريد ـ حُكه مونبر.تل داو ينوجي ددغبي مهمبي قضي خهبرونه يـا خهونه خبيريبي اوكه خجيريبي نسوُُيني مطبوعات اوراديو كاني مونبريه داسي نومونو

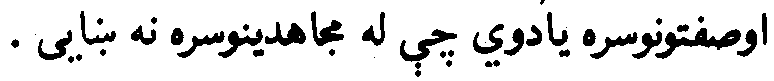

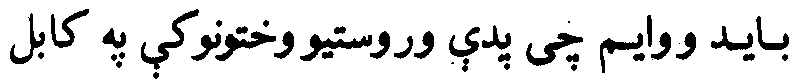
كي دروس دكوداكي دزيم بِ خوله اعلان شوي ملي سـولي دحيرانتيا ور اغيزه كريده آن تردي بوري دوري

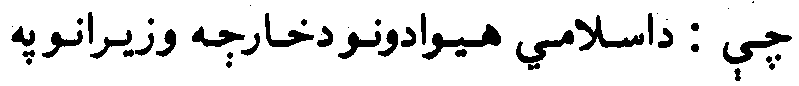
اجنداكي يج مم انعكاس كورو .

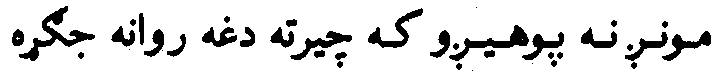

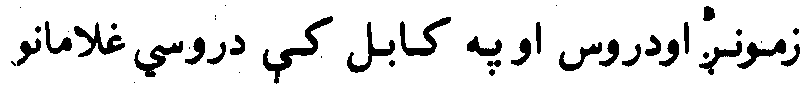
ترمسينُ وي خنكه كيداى ثي جب دلته دمبي سولي

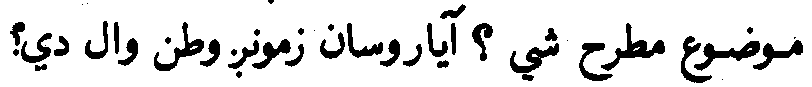

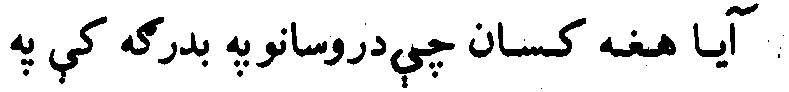
روسي تانكـونوسباره افغانستان ته راننوتل اودخبل 
وطن ، وطنوالو اوددي ميواد دعتيدي اودين به ضب يبي دجـكري اوربل كر ، ددي وطن زامن اوددي مئي

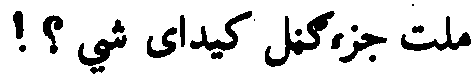
هو إكه روسي قواوي زميونبر. له ميواد نه ووحئي

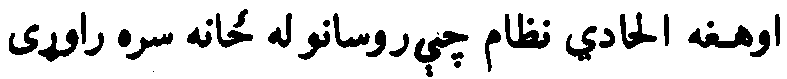

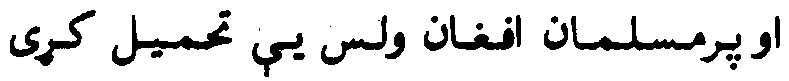
رانسـكورثي نوكه بِ مفه وخت كي دمسلمانو

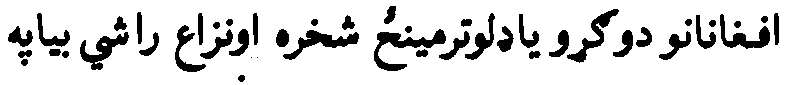
هغه وخـت كي كيداى ثي دملي سولي بير موضوع بحث وثي •

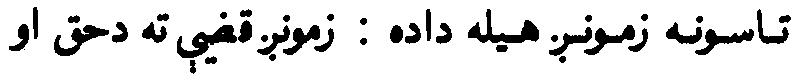

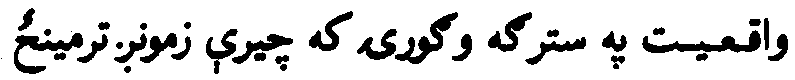

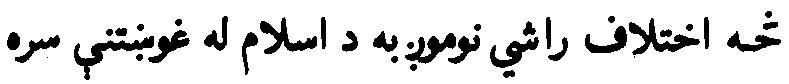
سم دالله جل جلاله بِ كتاب اودرسول الله مل الله عليه وسلم بِ سنت فيعله كوو، (( بإِها الذين آمنوا 
إذا تنـازعتـم في ثهيء فردوه اله الله والرسول ) )

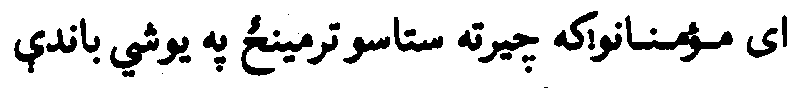
شخره راغله نواللة اودهغه رسول ته يج وداندي كئري.

\section{داسلامى ميوادونو مشرانو ورونو!}

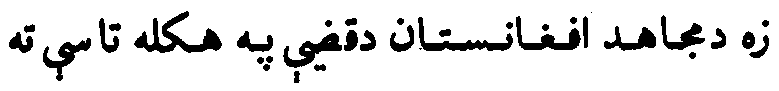

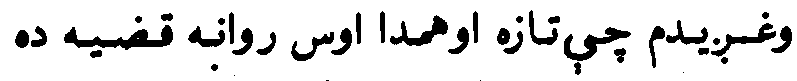

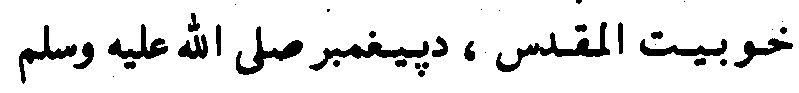

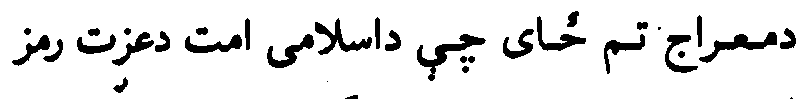

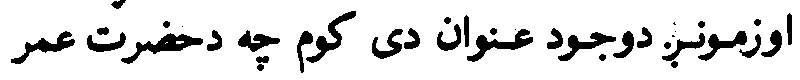

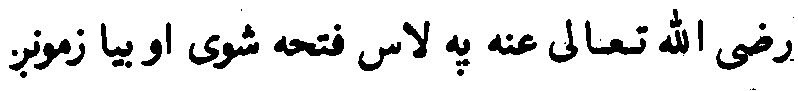

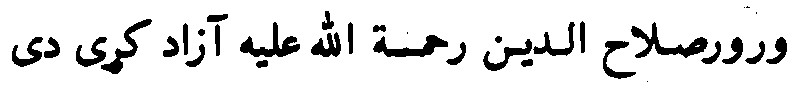

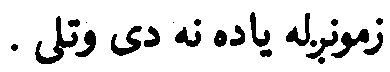

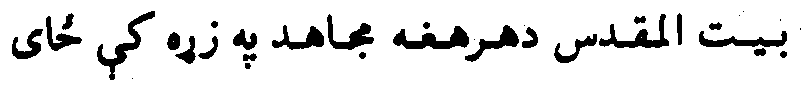
Ło 
اوتدرلري كوم جي دافغانستان به جهاد بوخت دي

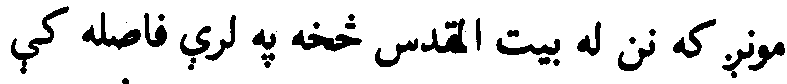

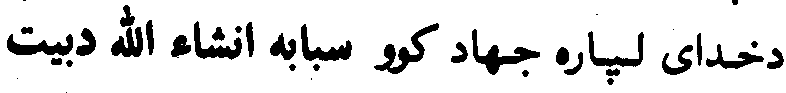
المقدس دآزادى لياره دمغه به بجاييريال كي

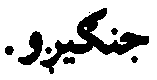

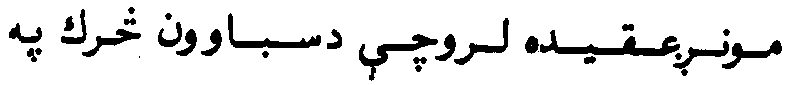

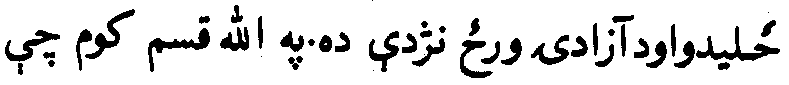

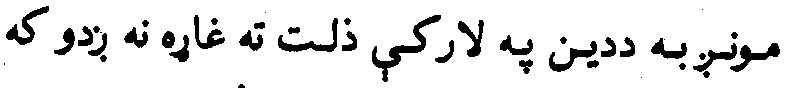

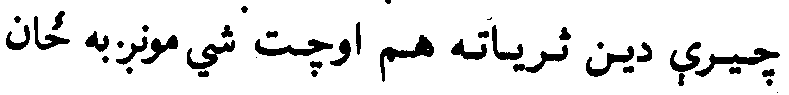
وررسو مونج. دالله جل جلاله له نصرت او ياد الله به لاركب له شهادت خخهه برته بله دحل لاره نه و ينو اوداجل

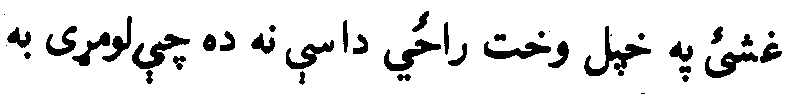

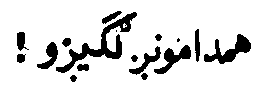
ددي نيك فرمست نه يه استفاده كولوسره دمعد 87 
صلى الله عليه وسلم تول امت ته خطاب كوم بجي : خجيل كرامت اوميبت بيرته راوكرحُوى له تيتي تروني

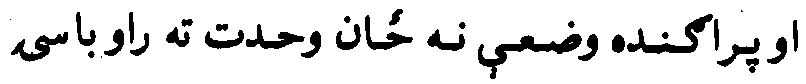

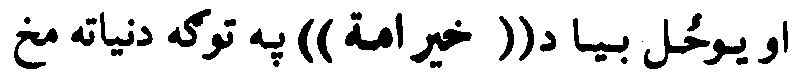
كرى يه نيسكو كازونو امر ورته وكرى اوله بدويج منعه كرى او يه الله رب العالمينبوره ايمان ولرى نهر. غنكي له دي خي خهيلي خبري باى ته ورسوم خبل باورخركندوم جـي : هيجي

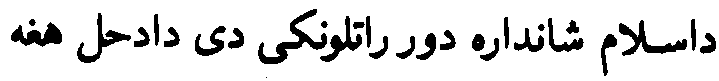

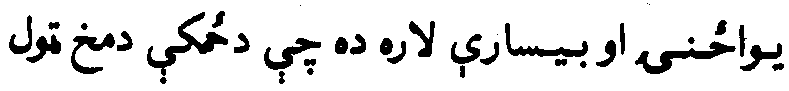

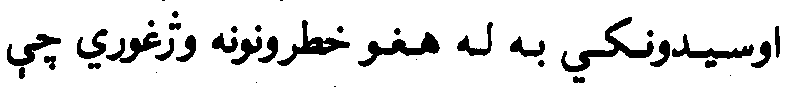

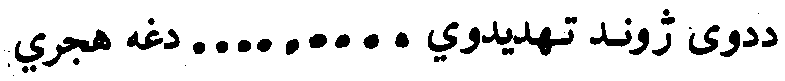

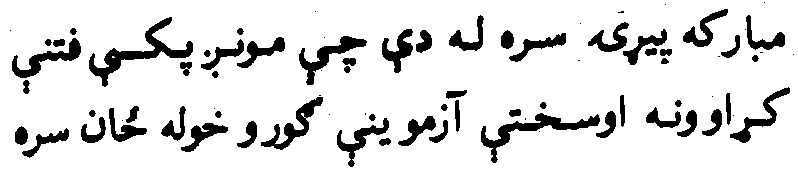


يسي دحُلانـده سباوُن ورانكي راوري دي ( ولقد

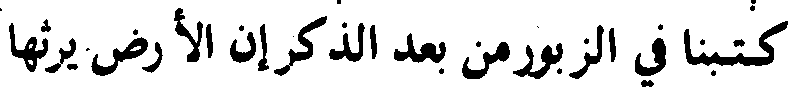
عبادي الصالحون إن في مذا لبلاغاً لقوم عابدين) مونب. به زبوركسب له نصيحت نه وروسته داليكلي

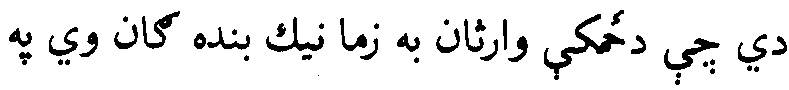
دي كي دعبادت كوونكو نجلكو لياره لوى خبردى. او به پياي، كسب دكو يت له دولت خهخه دبنبي ميلمه يـالني او داسلامي كنفرانس له تنظيم خخهه مونب. ته دوخـت راكولو له امله شكريياداء كوو اوهما راز

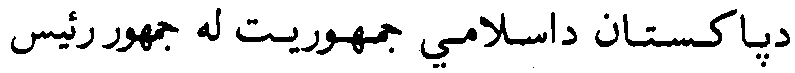

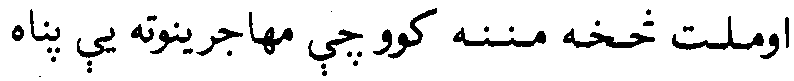
وركري او دجهاد دقضيى به باب يب دميرانب درئح

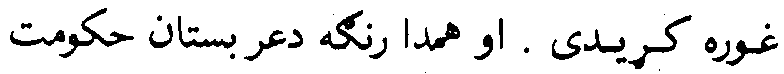

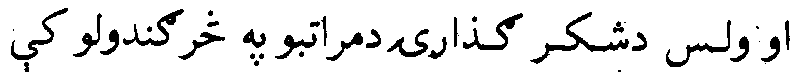




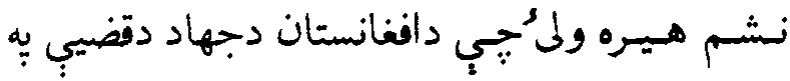

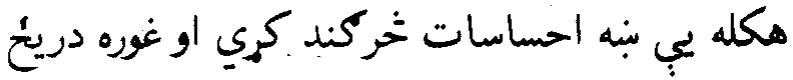

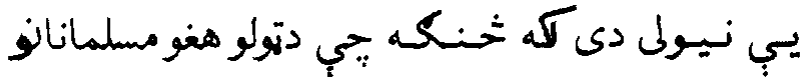

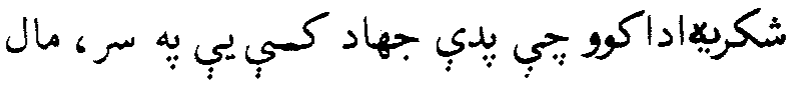

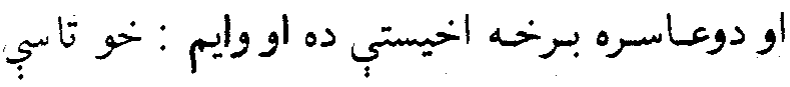
آمين رايسب وايعى!

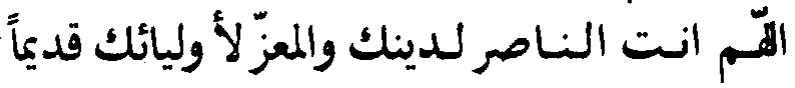
وحديـاً ، التم إفتح لنا فتحاً مبيناً وانصرنا نصراً

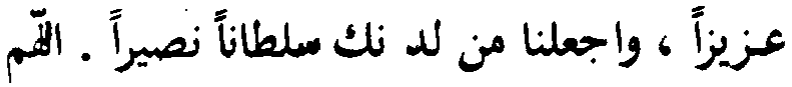

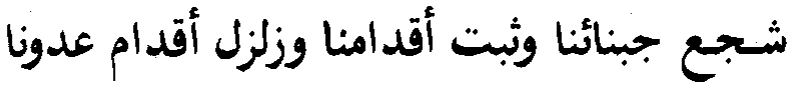

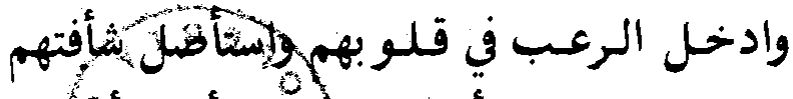

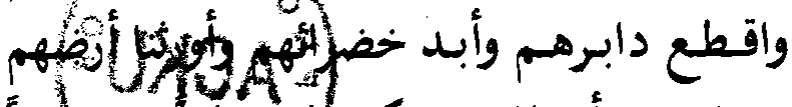

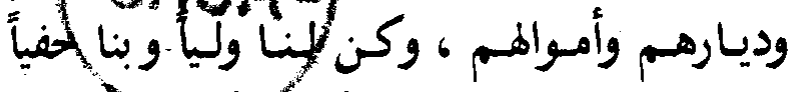

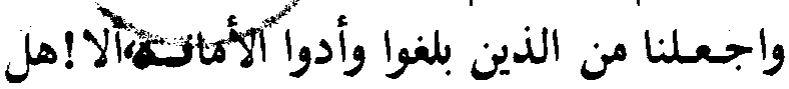

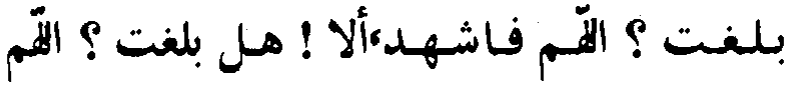




$$
\begin{aligned}
& \text { فاشهد ، ألا ! هل بلغت ؟ الآم فاشهد . } \\
& \text { وصلى الله تعالى على سيدنا محمد وعلى آله وصحبه }
\end{aligned}
$$

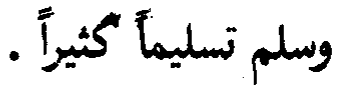

$$
\begin{aligned}
& \text { والسلام عليكم ورحمة الله وبركاته ! }
\end{aligned}
$$
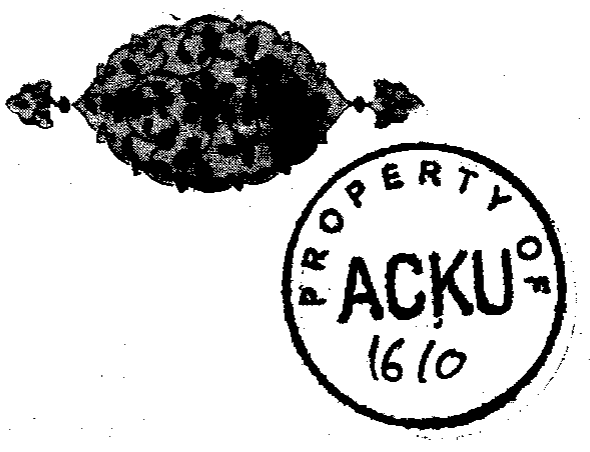


\section{$A \cap 10$}

B

4.3831

SAY

1610

خهروونكى : داسلامي اتحاد ددعوت اوارشادكميه .

شمير: ... . . جلده . . .

داسلامي اتحاد مطابع

كال : צוזrו הـ . 